Faculty of Economics and Statistics

University of Konstanz

\title{
Political Risk and Foreign Direct Investment
}

\author{
Lizenziatenarbeit
}

supervised by Prof. Dr. Heinrich Ursprung

Second supervisor: Prof. Ph.D. Albert Schweinberger

Author:

Guy Leopold Kamga Wafo

Konstanz 1998 


\section{Contents}

\section{Introduction}

\section{Theoretical Backgrounds}

\section{A. The Phenomenon of Foreign direct Investment}

1 The nature of Foreign Direct Investment

2. Recent Trends in Foreign Direct Investment

\section{B. The concept of political risk}

1. The concept of political risk in historical perspective

2. Definition of political risk

3. Sources of political risk

4. The relevance of political risk for FDI

\section{The management of political risk}

\section{A. Business responses to political risk; risk transfer and risk negotiation}

1. Political risk assessment

1.1. Subjective approaches

1.1.1. Grand tours

1.1.2. Old hands

1.1.3. Delphi techniques

1.2. Objective approaches

1.3. The political indicators

1.3.1. General political risk indicators

1.3.2. Partial risk indicators; the government stability indicator

2. Monitoring political risk

3. Integrating political risk in international capital budgeting

3.1. Understanding the process of integrating political risk into capital budgeting; An operational Model 
3.2. The Approach of Shapiro; Adjusting Cash flows

3.3. The Approach of Clark Ephraim

3.4. The approach of Arvind Mahajan

4. Understanding and monitoring conflicts between host countries and investing firms; The obsolescing bargain theory

\section{B. International Institutions and management of political risk}

1. International investment rules and management of political risk

1.1. The World Bank Group

1.1.1. The International Finance Corporation

1.1.2. The International Centre for Settlement of Investment Disputes

1.1.3. The MIGA (Multilateral Investment Guarantee Agency)

1.2. Multilateral Agreements

1.3. Bilateral Agreements on the protection of Investment

1.3.1. Bilateral State-to-State Agreements

1.3.2. Bilateral Investment Treaties (BITs)

1.4. Government Investment Guaranty Program ; The OPIC (The Overseas Private Investment Corporation)

\section{Operating Strategies for management of political risk}

1. Getting FDI projects ownership structures right; Joint ventures arrangements

2. Getting the financial structure of FDI project right.

\section{Empirical Studies on political risk and FDI}

\section{A. Empirical research on political risk, level of corporate risk and risk premium}

1. Empirical research on political risk and level of corporate risk

2. Empirical research on political risk and risk premium

\section{B. Empirical research on the linkage between political risk and FDI}

\section{Summary}

V. Conclusions; The need for a new comprehensive theoretical framework 


\section{Introduction}

Over the past three decades, Foreign direct Investment has been the major component of capital flows since firms domiciled in one country have established foreign branches and purchased foreign firms. Indeed Foreign direct investment has become the prime engine to foster growth and employment in the industrialized countries, to facilitate the development of less developed countries (LDCs) and the restructuring and internationalization of formerly socialist or sheltered areas. It is therefore not surprising that a global race for foreign direct investment is taking place worldwide ${ }^{1}$. A foreign direct investment implies a permanent relationship between the investor and the object and particularly the opportunity for real influence over the object's operations. Investments which do not fit this definition are to be classified as portfolio investments.

The aim of a Foreign Direct Investment, according to the definition of IMF, is to acquire a lasting interest in a enterprise operating in an economy other than that of the investor, the investor's purpose being to have an effective voice in the management of the enterprise. The definition of IFM includes extended trade credits from a parent to a subsidiary, acquisition of shares, loans from parent to subsidiary companies, a parent company's guarantee of a subsidiary's loan and self financing over and above the normal consolidation requirement. Profit retained in the foreign subsidiary should also be counted as Foreign direct investment. However exceptions to the IMF's definition are frequent. Japan and France, for instance, do not count retained profits in a foreign subsidiary as Foreign direct investment. The common view of the practical minimum of equity needed for an effective voice in the sense of the IMF definition in management, is a 10 percent ownership. Again France, Germany and the United Kingdom use other definitions. Hence, whenever cross- country comparisons are made regarding Foreign direct investment, attention has to be paid to differences in definitions ${ }^{2}$.

Foreign Direct Investment is generally of two kinds: The creation of productive assets by foreigners who build something new or alternatively the purchase of assets by foreigners, presumably because they think they can use the assets more productively than sellers. A small purchase of equity without control is considered as portfolio investment and therefore excluded from the scope of this essay ${ }^{3}$.

\footnotetext{
${ }^{1}$ See Oxelheim Lars (1993); The global race for Foreign Direct Investment, prospects for the future ed. by Lars Oxelheim, Heidelberg.

${ }^{2}$ Ibid., p. 11, Footnote 11.

${ }^{3}$ See DeAnne Julius (1991); Foreign Direct Investment, the neglected Twin of Trade published by Group of Thirty, Washington D.C., p. 2.
} 
FDI is another factor in the movement towards a global economy. Foreign investment flows increased by 30 percent annually throughout the 1980s, about three times faster than the growth of world exports and four times faster than world gross national product. The result is that the global production of companies where ownership and financing lies outside the host country now exceeds the total of world trade. For example, in 1992, some 207, 000 foreign affiliates generated sales of US $\$ 5,8$ trillion, while the value of global exports of goods and services was US $\$ 4,7$ trillion ${ }^{4}$.

It is clear that investment, as well as trade, has become an essential route to foreign markets. As business becomes more global and the level of competition continues to rise, managers will finds themselves facing increasingly complex strategic decisions. However, when one considers the prospects of international expansion and investment, one cannot help but become aware of the many and varied political risks facing international firms in these strange new lands. Indeed the last decades have confronted managers of multinationals with major changes in the political environment of the multinationals and the conditions for doing business. To begin with, the health of FDI and multinationals is more closely linked to foreign markets than ever before.

The most crucial markets are those where not only the opportunities, but also the commercial and political risks, are the greatest. Trade finance, risk management and business protection have become the sine qua non of links with Eastern and Central Europe, China, Japan, Southeast Asia. These big emerging markets include Mexico, Brazil, Argentina, India, Turkey, Poland, some African countries such as Uganda, Ivory Coast, South Africa, Mauritius. These countries are growing two to three times faster than the industrialized countries of the OECD. Yet most of the emerging markets are undergoing tumultuous political and economic changes.

From Indonesia to South Africa to Russia, the simultaneous opening of their economies and political systems is unleashing unprecedented demands and raising profound questions about their ability to sustain high growth, open market and political stability. Historically, multinationals have not been on the progressive end of change abroad, preferring political stability to the unknown. But like the Asia- and Russia- Crisis show, there will be no stability in the emerging markets in the years ahead. Political change will be constant and sometimes explosive. Multinationals need to manage this situation, not by opposing change, but by trying to move with it, even helping to lead it.

\footnotetext{
${ }^{4}$ See United Nations Conference on Trade and Development (UNCTAD) Secretariat (1995); Recent Developments in International Investment and Transnational Corporations; Trends in FDI, Geneva, 21 February 1995, p. 5 cited in Winham, Gilbert R.; International Trade Policy in a Globalizing economy, International Journal, Vol. LI, Nr 4 Autumn 1996, p. 641.
} 
It is also in the emerging markets that other political interests of FDI (human rights, labor practices, environmental protection, the reduction of corruption and nuclear proliferation) loom large and difficult decisions must be made in multinationals regarding an overall approach to FDI. This results in the transformation of the context in which the nation's interests are acted out. The new landscape is characterized by globalization of business, the political and economic fragility of many up-and coming investment partners and growing tension between values widely held by foreign investors and other economic and political goals of host countries.

These developments in the world investment environment, together with the increase of political risks, should by now have made the relationship between FDI and political risk a major concern. Yet existing economic research on the relationship between political risk and FDI tend to agree on the idea that FDI is supply-determined, that is, determined by the decisions of multinational enterprises. There is no real market envisaged for FDI. The demand in the host countries is implicitly assumed to be infinitely elastic. This suggests that the relation between political risk and FDI should be envisaged in the corporate perspective, that is, in the perspective of multinationals.

The relationship between political risk and FDI can also be seen in another perspective, namely in the perspective of the host countries. In the neoclassical growth model, capital should flow from capital rich countries to capital poor countries because it should earn higher returns. This does not explain why the majority of FDI takes place among developed countries rather than flowing from the OECD to the developing world. One explanation for this paradox could be found in the high political uncertaintity in LDCs. Thus, if LDCs want to attract FDI flows, they should make efforts to reduce political risk.

There are many reasons why economists and managers should make an effort to comprehend the nature and magnitude of links between FDI and its political environment. First of all, the last two decades and recently the Asia and Russia crises have confronted managers of multinationals with major changes in political environment of most industrialized countries and LDCs and the conditions of conducting business. At the corporate level this can only trigger increased uncertainty about political risk. On the other hand, the understanding of the relationship between political environment and FDI could also be used in risk management on a corporate level. It is worthwhile to note that increased political risk is not only a source of uncertainty, but also of tremendous opportunities. Furthermore, a good comprehension of the relationship between political risk and FDI could reinforce and strengthen the internationalization of capital flows and the volume of investments towards "risky" zones (mostly the LDCs) and thus contribute to the growth of World Trade. 
Moreover, the study of the relationship between political risk and FDI could be integrated in the pursuit of efforts aiming at erecting a genuine international investment law. Surely the analysis of relationships between political risk and FDI could also shed light on the role of the State in a globalizing world- in the sense that the study of political risk could be very telling about the relationship between politics and international economics.

Finally, a good comprehension of the relationship between the political risk and FDI could also help host countries to appreciate the possibilities and limits of their political governance upon the level and volume of FDI.

A better understanding of the influence of political risk on FDI calls for a new setting which involves three steps and this constitutes at the same time the structure and framework of this essay:

Firstly, the political risk has to be defined and assessed. For this purpose a new practical and normative-oriented comprehensive framework for assessment of political risk combining objective and subjective approaches and capable to be operational is needed. The ongoing measures of political risk do not satisfy these conditions.

Secondly, the concrete effect of political risk on the investment's outcome has to be measured. That means the political risk has to be fully integrated into the FDI theory, so that the correlation between the actual and potential events and the capital value of FDI can be correctly priced and quantified.

The third step concerns the reactions of the corporate management to the political risks as well as the efforts made on an international level to improve and stabilize the investment policy and rules.

Objectives of this exploratory and prospective study are threefold:

First to identify the political factors which could influence the level of equity involvement of the multinationals.

To see how these political factors influence specific financial parameters and the investment decision of multinationals.

To analyze to what extent, and in what way, the management of political risk could have a moderating effect on these parameters and to analyze the building blocks of the new international investment law.

It is worth noting that the general aim of this study remains the clarification of the question of how to shape the political consciousness of the decision-makers and how to deal with political risk on a corporate level. ${ }^{5}$

\footnotetext{
${ }^{5}$ It appears that the considerations of riskiness in international business sudies is an under-researched issue with ample room for studies that document the variability of outcomes and not just their means. See Caves, Richard (1998); Research on International Business Studies, Problems and Prospects, Journal of
} 
More specifically, the issues framed above as central and important organize this essay into three parts.

The first, which represents the definitional part of the essay deals with the problematic of definition and sources of political risk. The first part will also expose the difficulty to assign limits to the phenomenon of political risk.

The definitions and thematic context developed in part one situate the subject of part two, which deals with the question of management of political risk. This second part can also be termed the decisional part of the essay, for it is mostly oriented around the integration of political risk in the corporate decision process.

The third part is an empirical one. It concentrates on the different empirical researches made to grasp the nature, the effect and the magnitude of the relationships between political risk and FDI.

Finally, because the most striking observation to emerge from the analysis of the relationship between political risk and FDI is that the nature and logic of this relation lies in the realm of the interplay between political Nation-States and markets or economics, the conclusion will look closely at the nature of this interplay and at the implications for our subject.

International Business Studies, Symposium Multinational Enterprises and Economic analysis, Vol. 29, Nr. 29 , p. $5-19$, p. 9. 


\section{Theoretical Backgrounds}

\section{A. The phenomenon of Foreign direct investment.}

\section{The nature of FDI}

Foreign Direct Investment (FDI) has grown dramatically as a major form of international capital transfer over the past decade. Between 1980 and 1990, world flows of FDI -defined as cross-border expenditures to acquire or expand corporate control of productive assets have approximately tripled. FDI has become a major form of net international borrowing for Japan and the United states (the world's largest international lender and borrower, respectively) ${ }^{6}$. The FDI first came to play a key role in international finance and trade after 1985. The surge of FDI after 1985 was largely a surge in investment flows among industrialized nations. The fate of national economies have become increasingly linked with the economies of other nations. One main force behind this phenomenon, also termed globalization, is one over which politicians have little or no control: the surge of multinationals.

The economic implications of Foreign Direct Investment are complex. Foreign Direct Investment, on macroeconomic level, is variously portrayed as: a welcome new source of jobs by depressed regions; a balance of payments flow that finances half of the US current account deficit and recycles most of Japan's surplus; a vehicle of technology transfer; a tool with which global companies can gain strategic advantage by shifting low paid jobs abroad, while keeping high-value-added research at home, and an insidious way for foreigners to buy into a country's productive assets. Especially for the LDCs, the FDI represents furthermore an efficient instrument for technology transfer, for export promotion and an access to foreign exchange. Moreover, in recent years FDI has become a predominant source of international finance for LDCs, substituting commercial bank loans which lost importance as a result of the international debt crisis. On the micro-economic level investment, possibilities abroad enhance the competitive set of domestic investment opportunities.

One of the controversial issues associated with FDI concerns the question of measurement or definition of FDI. In principle, firms could become multinational or increase their operations abroad without any international movement of capital per se. For example, a British firm could acquire a U.S. firm with funds borrowed in the United States. In this case, there would be an increase in the share of the U.S. economy controlled by foreign firms, but

\footnotetext{
${ }^{6}$ See Froot Kenneth. A (1993); Foreign Direct Investment, ed. by Froot Kenneth A, The University of Chicago Press, p. 1.
} 
no inflows of capital. Ideally, therefore, the analyst should measure the growth of multinational enterprise by looking directly at the share of each economy controlled by foreign firms rather than by looking at capital movements. Unfortunately, numbers on the share of economies controlled by foreign firms are unreliable and lag well behind actual events. As a result, it is necessary to rely on other measures of FDI ${ }^{7}$.

The most commonly used measure of FDI make use of flows of FDI, as they appear in national balance-of-payments accounts. The balance-of-payments accounts define direct investment as that part of capital flow that represents a direct financial flow from a parent company to an overseas firms that it controls. Accounting standards vary from country to country, resulting in some problems of consistency when national figures are aggregated.

By International Monetary Fund (IMF) standards, however, FDI consists of the sum of (1) new equity purchased or acquired by parent companies in overseas firms they are considers to control (including establishment of new subsidiaries) (2) reinvestment of earnings by controlled firms, and (3) intra-company loans from parent companies to controlled firms ${ }^{8}$.

The activities of multinationals can be developed in various ways or forms. It is customary in economic literature to distinguish two forms of private investment or long -term international capital movement. The portfolio investment and the Foreign Direct Investment. The distinction is in fact based on the question of who controls the company in which the investment is made. If the investor has a direct and effective control over the foreign enterprise, his investment is called Foreign Direct Investment. If he does not control it, his investment is termed a portfolio investment.

One of the most serious problems encountered in this common control-oriented distinction between the FDI and the portfolio investment derives from the various and arbitrary definitions of "control." Indeed, if we look at the definitions of control in the national legislation of industrialized countries, we find a range of distinct definitions depending on the national interest pursued by the country concerned. For instance, France and Germany consider a foreign enterprise to be French or German-controlled if it's wholly owned, or if 10 percent of the equity is held by citizens of France or Germany 9 .

\footnotetext{
7 Graham M. Edward and Krugman Paul R. (1993); The surge in Foreign Direct Investment in the 1980s, in; Foreign Direct Investment ed. by Froot Kenneth A. University of Chicago, p. 13-36, here p. 14-16.

8 Ibid.

${ }^{9}$ For the reasons behind the distinction between Portfolio Investment and Foreign Direct Investment see Hymer Stephen Herbert (1976); The International Operations of National firms, a study of Direct Foreign Investments, the MIT Press, Cambridge, London, England, pp. 3.
} 
Generally, Foreign Direct Investment is a term used to denote the acquisition abroad of physical assets, such as plant and equipment, with operational control ultimately residing with the parent company in the home country. It may take a number of different forms including ${ }^{10}$ :

- The establishment of an existing overseas branch or subsidiary

- The acquisition of an overseas business enterprise or it assets

Investment in the form of FDI began before the First World war when people of Western Europe used a greater fraction of their current savings and income to finance foreign governments and enterprises in other parts of the world than ever before or since. ${ }^{11}$ Almost all the FDI of Europe (Great Britain, France and Germany) were made during this period in the form of creation or financing of mines, plantation fields, public utilities, railways and ports, mostly in Africa and Latin America. During this period Great Britain, as the great imperial power at that time, dominated the international business with over 45 percent of the World's total stock of FDI in $1914^{12}$. After the Second World War, the FDI league leadership passed to the USA with American companies such as General Motors, IBM and ITT developing manufacturing bases around the world- mostly in Europe and Latin America. By 1960 the USA accounted for over 48 percent of world FDI ${ }^{13}$.

Afterwards this leadership by the USA was followed by the re-emergence of European multinationals, and the entry of Japan into the international investment scene.

It is also worth mentioning the emergence of some LDCs countries as foreign direct investors. This is particularly the case of the emergent countries (Tiger countries) or some of Latin American countries. For a long time, FDI came exclusively from the major industrial countries. Recently the sources of FDI have widened and many LDCs have emerged as sources in their own right, particularly for their own region ${ }^{14}$. Regional links are also important for FDI from developed countries. FDI provides LDCs with financing of their growth, it introduces them to new technologies, management techniques, and market access. Indeed, trends in FDI in LDCs have reflected changes in policy stances by developing countries, from import substitution in the 1950's and 1960's through natural resource-led

\footnotetext{
10 Buckley Adrian (1996); Multinational Finance, third edition, Great Britain, p. 35.

11 See for history of Foreign Direct Investment Feis Herbert (1965); The World's Banker (1870-1914), a Account of european Foreign Investment and the Connection of World Finance with diplomacy before Word War I (IX preface), Yale University Press.

12 Buckley Adrian; ibid. p. 36.

13 Ibid. p. 36.

${ }^{4}$ See Miller, R. R (1996); International Joint Ventures in developing Countries, IFC Discussion Paper 29, Washington DC.
} 
development in the 1970's, structural adjustment and transition to market economies in the 1980 's, and an increase role for the private sector in the 1990's. ${ }^{15}$

The globalization and liberalization of trade and investment has led to a dramatic surge in FDI flows to developing countries which increased fivefold from 1990 to 1995 and exceeded $\$ 100$ billion in $1996^{16}$. However, this increase went mainly to 12 large developing countries, in part reflecting their economic size. Although the actual amounts of FDI invested in LDCs are generally low, reflecting partly the small size of their economies, FDI relative to GDP in poorer countries is as high as in richer countries. Countries in South Asia and Sub-Saharan Africa, lag behind in the volume of FDI flows relative to GDP however. ${ }^{17}$

The nature of FDI in LDCs has undergone a great transformation due to the emergence of new forms of FDI. Given the difficulties encountered with many developing countries and the high risk associated with the investment in LDCs, FDI is nowadays developing into new forms of investment which are better adapted to peculiarities of investment climates and finance of LDCs. Because of their constituent elements, which are contractual and associative, the new forms of FDI demonstrate an outstanding flexibility in this respect. They open new sectors for FDI in LDCs and provide medium-sized enterprises with new opportunities. This new development in the FDI structure towards more flexibility demonstrates clearly that the structure and nature of FDI among industrialized countries should be distinguished from the structures of FDI in LDCs.

Compared to domestic investment, FDI appears to be more risky and expensive. Due to the lack of information regarding foreign markets and to the sovereignty of the foreign countries, turning to FDI involves a range of costs, expenses and risks. Given the disadvantages of FDI, the main concern about the FDI in contemporary economic literature has been its justification. In other words, why do companies perform FDI? This crucial issue, which is also referred in economic literature as "The economic theory of FDI" deals with internationalization of corporate activities. The consequences of multinationals in foreign countries have then sparked new concerns on the corporate level about the effects of the political risk associated with FDI and the techniques to control it.

The surge in Foreign Direct Investment in the past decades is linked to the positive attitudes of States towards Foreign Direct Investment during these periods. This positive attitude towards the MNCs contrasts in fact with the overwhelming negative attitude towards them during the period between the 1960's and 1970's. The attitudes towards the MNCs reflects

\footnotetext{
${ }^{15}$ See International Finance Corporation (1997); Foreign Direct Investment, Nr 5, Lessons of Experience, Washington DC, p. 1.

${ }^{16}$ Ibid; p. 2.

${ }^{17}$ Ibid; p. 2.
} 
the controversial nature of Foreign Direct Investment and suggests the nature of difficulties encountered by the MNCs.

\section{New trends in FDI}

During the last decades there have been some clear changes related to the Foreign Direct Investment compared to the earlier situation. One of the existing changes in FDI is a structural one. Formerly FDIs were made particularly in the extractive industries, but during the last decades most of investments have been made in the manufacturing sector and increasingly also in the service sector.

The second change consists of a shift in the direction of FDI's; the relative share of amount and value of FDIs and accumulated capital stock in OECD countries has clearly increased, especially in Western Europe and in the USA.

Thirdly, whereas FDIs were formerly made by firms mainly from the US and the UK, during the past decades they have been made increasingly by firms from Germany, Japan, France and smaller OECD countries, and even NIC (New Industrialized Countries).

Fourthly, earlier FDIs were made by big multinational corporations, but in the recent decades (1970's and 1980's) FDIs have been made by an increasing number of medium-sized and even small firms

Fifthly, a clear trend related to the FDIs has been the increase in the liquidation and voluntary divestment of FDI, as well as the increase in FDI in forms of mergers and acquisitions particularly in developed countries.

Finally, while earlier FDI's were carried out in a politically hostile environment, in recent decades the FDI's have been operating in a more "positive" environment characterized by a race of governments for $\mathrm{FDI}^{18}$.

Undoubtedly, foreign investors in developing countries face many kinds of political risks due partly to the lack of political stability and of political capability of these countries. That FDI in LDCs is confronted with political risks is by the fact shown that most international investment rules, as well as public and international political risk-insurance, deals mostly with political environment in LDCs. Indeed, most political risk indicators are exclusively conceived for LDCs.

Given the common emphasis on political risk in LDCs, it is tempting to conclude that the such political risks do not exist in industrial nations. Such a conclusion is however very misleading for it does not take into consideration the various restrictive policy measures in industrialized countries which represented a political risk in real sense of this term for FDI

18 See Larimo Jorma (1993); Foreign Direct Investment Behaviour and Performance, an Analysis of finnish manufacturing Investments in OECD countries, Acta Wasaensia, $\mathrm{Nr} 32$, Business Administration Nr 13, Universitas Wasaensis, VAASA, p. 13. 
and particularly for those FDI in the form of mergers and acquisition. A short overview of the attitude of some important industrialized countries like Germany, Japan and the USA towards inward FDI could help to grasp the nature and magnitude of such FDI impediments.

The US-approach to FDI has long been grounded in the principle of natural treatment. Foreign investors are generally treated for regulatory, tax and other purposes as if they were domestic investors. However, the federal government does retain the authority to block inward investment that is deemed to be harmful to national security, especially in cases where foreign government interest lies behind an investment and in cases where dual military-civilian technology are in play.

The institution directly responsible for addressing such concerns is the Committee on Foreign Investment in the United States (CFIUS). Created as an oversight body in 1975, CFIUS is an inter-agency body composed of officials from the Department of State, Commerce, Defense and Justice, the Office of USA Trade Representatives, the Office of Management and Budget, the Council of Economic advisers and the Treasury.

The authority of CFIUS was made explicit in the EXON-FLORIO provision in the Omnibus Trade and Competitiveness Act of 1988, which empowered the president to veto any takeover of a US firm on national security grounds. During the most active period of FDI in USA between 1988 and 1992, for example, CFIUS received 700 cases deemed worthy of review. It subjected 13 of those to a 45 days extended review and sent nine cases to the President's desk for decision.

In eight of those nine cases the President took no action. In the case of the attempted purchase of General Ceramics Ltd by the Tokuyama Soda Co. of Japan, CFIUS recommended that the acquisition be blocked because the US firm was a supplier of nuclear defense technology. The sale eventually went through after the firm's nuclear operations were spun off and sold to an American company. ${ }^{19}$

Germany's approach to inward direct investment is in some aspects as restrictive as the USA approach, especially concerning the FDI in Germany in form of mergers and acquisitions. Indeed with the exception of legislation introduced in the mid-1970s to protect specific national assets (such as Daimler Benz) from foreign take over, German law imposes few restrictions upon inward investment. The most powerful domestic factor that affects FDI in

19 See Doremus Paul. N, Keller William W. et al (1998); The Myth of the global Corporation, Princeton University Press, p.76-77.; See also Commission of the European Communities (1992); Report United States Trade and Investment Barriers, Problems of doing business with the US Brussels, Commission services, Belgium April 1993; See Graham Edward M ; FDI in the United States and U.S. Interests, Science Vol 254, Dec 20, 1992, pp. 1740-45. 
Germany is Germany's distinctive corporate governance structures. Germany's strong bankcentered corporate networks can often effectively impede unwanted corporate take-over. As a result, much of Germany's industrial base remains comparatively insulate from foreign incursions. ${ }^{20}$

Japan's approach to inward investment is more restrictive than Germany's approach for mergers and acquisitions, and foreign companies have been discouraged by regulation such as weak intellectual property protection, regulatory burdens and custom ${ }^{21}$. As a result foreign firms rarely merge or acquire Japanese firms. Since mergers and acquisitions are so difficult in Germany and Japan, inward FDI in both countries usually occurs through green field establishments and joint ventures.

\section{B. The concept of political risk}

\section{The concept of political risk in historical perspective}

The concept of political risk as a field of scientific research has gone through an important evolution over the past decades. Jonathan Barron Baskin and Paul J. Miranti, in their study of the evolution of corporate finance, suggest that before the First World War, in the seventieth century to be precise, attempts were already made by international companies to deal with various sorts of risks including political risks. ${ }^{22}$ According to Jonathan B. and Paul $\mathrm{J}$. the formation of close and abiding relationships with the state was one effective means used by promoters of international companies to assuage the concern of prospective investors about the risks of large-scale trading ventures in the seventieth century. Such an approach was followed by the East India Company's organizers who sought to overcome the reluctance of investors to invest their capital to an inherently risky undertaking by associating it with the assurance of national powers. ${ }^{23}$

Though signs of political risk and measures to overcome it could be traced to the seventieth century or beyond, the scientific consciousness and reception of the concept of political risk in economic literature is historically linked to the political events of 1960's whereby new independent countries tried to overcome their lack of capital by simply taking over the foreign subsidiaries of multinationals. On the other hand, the reception of the concept of political risk in economic literature was also due to the surge of collective economic theory (Marxism) at the beginning of the 20th century, which led in most industrialized countries

\footnotetext{
20 See Doremus Paul, Keller William W. et al; Ibid., p. 78.

${ }^{21}$ See Doremus Paul, Keller William W. et al; Ibid., p. 77.

22 Barron Jonathan, Miranti Paul. Jr, A. (1997); History of corporate finance, Cambridge University Press, p. 83.

${ }^{23}$ Ibid., p. 83.
} 
and in LDCs countries to nationalization and political control over the activities of multinationals.

In the 1960's confiscation, expropriation and nationalization became critical concerns for companies with foreign operations. These increased concerns about political risk was treated in economic literature mostly in the conceptual framework of the relations between host countries and multinational enterprises.

The field of political risk research became more complex after the 1979 fall of the Shah of Iran, as questions of political stability were added to the variables being examined, that is to confiscation, nationalization and expropriation ${ }^{24}$. The extension, or enlargement of the political risk scope to political instability was followed by initial attempts in economic literature to quantify and clarify the concept of political risk defined as a mechanism for the objective evaluation of foreign investment climates. In addition, this enlargement of the political risk scope gave birth to a variety of economic studies related to the methods or approaches used to assess scientifically the political risk. Among these studies, it is worth mentioning the paper of Rummel and Heenan, ${ }^{25}$ which was one of the first studies dealing with the assessment of political risk and proposing a method of converting polemical instability into probabilistic terms thus providing a scientific definition of political risk.

Another attempt to scientifically define and assess political risk can be found in the Business Environment Risk Information Index(BERI), which was developed by F. Theodore Haner as a quantitative guide to political risk ratings. BERI reviews more than forty-five countries three times a year and is based mainly on the judgments and appreciations of a panel of outside experts which try to rank countries according to fifteen factors affecting business climate.

In the 1980's more precisely in 1979, William Coplin and Michael O'Leary also began to develop the Political-Risk Services (PRS) evaluation system. This variety of political indexes was widely utilized by multinationals in the 1980's. From 1980's up to today, new approaches to political risk were also developed in economic literature. One distinguished feature of these new approaches is their effort to value the political risk and integrate it into the decision-making process of an enterprise, as well as their use of economic-political variables for the assessment of political risk.

To summarize, one could say that through its historical evolution, the concept of political risk has undergone three transformations which can be characterized as follows:

${ }^{24}$ For the historical evolution of the concept of political risk see Fry Earl H.(1983); The Politics of International Investment, New York, Mc Graw-Hill Book Company, p. 57-60.

25 Rummel Rudolf and Heenan David A. (1978); How Multinationals analyze Political Risk, Havard Business Review, January-February 1978, p. 67-76. 
From antiquity to the 1960's: the period of banalization of political risk in the sense that although the manifestations of political risk were taken into account in the investor's strategies, there was neither an elaborated concept of political risk nor a precise political risk consciousness.

The 1970's: the period of political risk consciousness at corporate level and ideologization of political risk in the sense that the main sources of political risk during this period were motivated by ideological views (Nationalism and Marxism). Put in other words, one can say that the birth of the concept of political risk was linked to the spread of collective doctrines. Since the 1980's; the period of scientification and professionalization of the concept of political risk in the sense that one main feature of this period was the birth of quantitative risk assessment methods, the probabilistic interpretation of political risk and the systematic use of these quantitative approaches on the corporate level and by the professionals.

Since the 1990's: The period of the scientific refinement of the political risk concept through the contributions of other fields of research such as political science, sociology, decision theory and psychology and the interdisciplinarity between political science, and economics in the political risk research.

\section{Definition of political risk}

As manifested in the previous chapter, investors have a great significance in their overseas investments and operations with non-financial risks. Because of the importance and significance of political risk for FDI, political risk definition must become one of the essential tasks of international investors. Moreover a definition of political risk is a prerequisite for any kind of analysis on it. Thus, in considering the relationship between political risk and FDI, it is first necessary to recall what political risk is and to relate it to its sources.

Though all investors are confronted with a certain non-financial risk in their overseas investment, the magnitude, nature and direction of these non-financial risks are uniquely dependent on the nature and size of the investment and therefore on the objective followed by a given investor. This feature of non-financial risk highlights at the same time the difficulties faced by political risk analysts, namely, that the implications of the term political risk vary with the interests and need of the definer that is of the corporate, a private insurance firm, a bank or a multinational organization (for example IMF) are likely to define political risk quite differently ${ }^{26}$.

Accordingly, there exists in the economic literature different ways of defining political risk. Indeed the definition of political risk depends on the perspective in which ones views the

${ }^{26}$ See Haendel Dan (1979); Foreign Investments and the Management of Political Risk, Westview special studies in international Economics and Business, p. 5. 
political risk and on the importance one attributes to political risk. Thus, the content of political risk definition can be extensive or restrictive. The exclusive definition of political risk includes in the sources of political risk concept all kinds of political motivated acts no matter where these are rooted. In this perspective, sources of political risk are seen in government instability as well as in societal instability. Moreover, predictable, as well as unpredictable political events are also viewed in this perspective as essentially political. This means unpredictability is not constitutive of political risk definition. Even economic variables, in so far as they are related to monetary and fiscal policy enter in this extensive definition of political risk. One example of extensive definition of political risk is offered by Agmon (1985), who defines political risk as the unanticipated changes in political factors that affect the relative prices of traded factors of production, goods and services caused by the actions and reactions of governments and other political groups within and between countries. ${ }^{27}$

The restrictive definition of political risk in contrast to the extensive definition encompasses only political instability stricto sensu- that is political risk that is originated exclusively in the state activities. Furthermore, only unpredictable political events are accounted in this perspective for political risk. Both the extensive and restrictive political risk definition are descriptive and non-economic.

Viewed as a financial phenomenon, political risk can be defined as unpredictable demands raised by foreign state or society on the assets, returns or cash available for shareholders from corporation international investment. A good descriptive definition of political risk is provided by Robock and Simmonds. ${ }^{28}$ For Simmonds and Robock, political risk in international investment exists when discontinuities occur in the business environment, when they are difficult to anticipate, and when they result from political change.

The descriptive nature of the above mentioned definitions of political risk and, as regards the financial definition, its partial perspective reduce the attractiveness of these definitions. An operative and normative criterion for the definition of political risk can be derived from the concept of "essential state". Essential state can be defined as classical functions of the states in a neo-classical sense. This entails justice, police, foreign affairs and set-up of efficient institutional arrangements. In this normative perspective, political risk could be defined as all measures of the foreign state which are not part stricto sensu of the essential state.

27 Agmon Tamir (1985); Political Economy and Risk in World financial Markets, USA/Canada, p. 7.

28 Robock, S. H. and Simmonds, K (1973); International Business and multinational Enterprise, R. Irwin, Homewood. 
To sum up, in spite of the widespread coverage of the subject, political risk has not received a clear cut definition. The definition of political risk which inspired this essay is borrowed from Dan Haendel because of its simplicity and practicability. He defines the political risk faced by foreign investors as "the risk or probability of occurrence of some political event(s) that will change the prospects for the profitability of a given investment ${ }^{29 "}$. However, for a full understanding of the phenomenon of political risk, this formal definition should be completed by an descriptive enumeration of political risk concerns of the foreign investors which at the same time represent political stability elements. The major political risk concerns of foreign investors could be viewed as follows ${ }^{30}$ :

1. stability of local economy, and absence of high inflation

2. fair and equal treatment from the host government

3. freedom from arbitrary and changing government regulation

4. free transfer of profit from the host country and

5. ability to sell or liquidate investment and subsequently, to withdraw funds from the country

6. the political willingness and ability to make structural reforms. The ongoing economic crises in Asia and Russia show that the political reluctance to conduct structural reforms are considered also as a political risk.

\section{Sources of political risk}

Political risks manifest themselves in diverse ways. Many attempts have been made in economic literature to catalogue and classify the various sources of political risk. The following descriptive classification of sources of political risks provides an overview of different sorts of political risk. It relies on the assumption that the greatest source of political risk is in the daily activities of the government. One possible motive for the activities of the government could be derived theoretically in the concept of rent-seeking groups as propounded by Krueger (1974). He states that whenever a government restricts the otherwise market-oriented economic activity, there is a potential rent. The existence of rent or potential rent initiates action by a rent-seeking group which could act as groups or as loosely organized individuals. Rent-seeking is an additional cost for the society and economy in general because the activity of rent-seeking groups contributes to a higher level of political uncertainty in a given economy and therefore hinders the FDI.

\footnotetext{
${ }^{29}$ Haendel Dan ; Ibid., p. 5.

30 See Eng v. Maximo et al. (1998); Global finance 2nd ed., USA, p. 427.
} 


\section{Manifestations of political risk}

I. Restrictions on entry by foreign direct investors

- restrictions on the proportion of equity a foreign investor may hold in an enterprise

- restrictions on the types of enterprises that foreign investors may undertake

- restrictions on ownership

II. Systems for Controlling inflows of FDI

- outright ban in selected industries (e.g. exclusion of FDI in a number of important sector specified in a negative list)

- vague criteria on official approval of FDI

- high taxes and weak incentives

- equity limits

- local content requirement rules

III. Limits on Foreign exchange transfers

- blocks to capital and profit repatriation

- long repatriation delays

- imits on repatriation by net worth

- limits on repatriation by foreign exchange earnings

IV. The role of the State in the economy: Government intervention

- Price controls

- Setting prices for natural resource exploitation

- regulating monopolies

- large state enterprise sector

V. Societal instability

- fragile political structures

- weak organizational level in the society

- corruption

VI. Political violence

- criminality

- putsch

- civil war

- civil disobedience

- riots 
VII. Government incapability

- inability to regulate the economy and conduct reforms

- lack of democratic institutions and spirit

VIII. Turbulent relations to international organizations

- Turbulent relations to IMF and World Bank

- Turbulent relations to UN

IX. Lack of commitment to international environment and labor rules (for if the government did not conform to such labor and environment standards the MNCs run the risk of being criticized or boycotted in other markets and in particular in industrialized markets. This situation can influence the level of estimated outcomes of MNCs)

$\mathrm{X}$. Turbulent relations to the foreign investors in the past five years

- lack of commitment to bilateral investment rules

- subtle expropriation of gained returns

XI. Hostile attitudes of elites and society towards the FDI

- hostile declarations of parties

- hostile programs

XII. Hostile attitude towards foreigners

- violence against foreigners

- intolerance towards foreigners

- restriction on expatriate labor

XIII. Reluctance of host countries to reveal reliable information

- Lack of transparency

- Secrecy of most political and economic decisions

\section{The relevance of political risk for Foreign Direct Investment}

With the surge of FDI in the past decade and in light of current trends and experience already gained by multinationals, new interest has arisen in the factors that determine and influence the flow of such an investment. In recent years studies on the determinants of FDI has moved to the centre of attention in policy discussions and in the literature on international finance. Academic researchers have then made various, more or less successful 
attempts to identify those factors influencing the flow of FDI. These can be divided into two categories: economic and political factors.

Although the relationship between the volume and nature of FDI and the political risk still remains empirically controversial, political risk has nevertheless been recognized as additional risk in the corporate perspective and as a factor which could dampen growth from the host-country perspective. Invest abroad generally implies additional costs apart from the normal costs due to the lack of knowledge about the foreign market and on the other hand to the uncertainty of the investment climate. The level of corporate risk may be influenced by political factors: host government expropriation, fund remittance control, differences in governmental and cultural practices and regulations, and political instability. This results in a greater exposure to political risk for the corporation.

Apart from the general costs and risks associated with any kind of investment, be it foreign or domestic, (credit risk, market risk etc.), investing abroad is determined by factors in addition to those which determine the risk of domestic investment cash flows. These additional risks are the results of the "foreign nature" of the foreign market and include currency risk, culture risk, and political risk, since all these tend to increase the uncertainty of the future expected cash flows from abroad. ${ }^{31}$

Dani Rodrik (1997) has argued that it is impossible to understand the East Asian growth miracle without appreciating the important role that government policy played in stimulating private investment. He shows that there is a strong correlation between good institutions and East Asian economic growth. Rodrick identifies four dimensions to good institutions: The quality of bureaucracy, with autonomy from political pressure and good recruitment and training; the rule of law, with strong political institutions, courts and an orderly succession of power; the low risk of expropriation including nationalization or confiscation; and low risk of repudiation of government contracts. East Asian growth does not seen to due solely to the accumulation of inputs, but also to institutional quality and to political stability. As discussed in the context of the East-Asian economies, there appear to be at least two important conclusions for successful economic development: first, political risk matters; second, openness matters.

Most recent studies in economic literature come to the conclusion that the key investment parameters on which managerial decisions should made, such as the level of investment, mode of investment and risk premium requirements, are influenced by political factors.

${ }^{31}$ See Chase C.D /Kuhle J.L /Walther. C.H.(1988); The Relevance of Political Risk in Direct Foreign Investment, Management International (MIR), Vol. 28, 1988/3, p. 31-38. 
Though most economists generally agree on the fact that political factors have an effect on the level and volume of FDI, they are rarely as certain however about the nature and magnitude of that relationship as well as on the concrete effects of political risk on FDI and sometimes they aren't even sure of the direction. This disagreement about the nature, the magnitude and the direction of the influence of political risk on FDI reflects the general conceptual inconsistency of political risk and particularly the difficulty to define and quantify it. The heterogeneity of political variables or factors makes it very difficult to isolate the phenomenon of political risk and to capture and measure its effects on corporate level.

Both earlier and more recent research on the relevance of political risk to FDI shows that the main determinants underlying the decision to invest abroad and the form of investment as well as the timing of investment, were principally market prospects and costs or risk factors in the light of overall corporate strategies. Political risk obviously influences cost and risk considerations and this may have an impact, particularly during a period characterized by a heightened cost and risk consciousness.

Especially in less developed countries where risk and cost considerations are seen by business as more permanent and more geared to the fundamental soundness of the prospect, political risk appears to have a very great significance for foreign investors. In his study concerning the examination of multinational capital structure, Burgman(1996) concludes that factors, such as increased exchange rate risk, great exposure to political risk, and greater tax uncertainty- may increase the risks of multinational relative to domestic companies $^{32}$. These factors may increase the risk to the firm's cash flows and therefore may increase the systematic risk to the firm- that is the standard deviation of the firm.

Indeed, there is a general trend towards some reduction in the overall level of government intervention which is associated which greater efforts by countries to use general economic policies to improve the economic climate, to encourage growth and to reduce uncertainty and instability ${ }^{33}$ The greater reliance of governments on the role of market to guide investment decisions should not lead however to the conclusion that the importance of political risk has then been reduced. The fact that every country in the world- to a varying degree- employs investment incentives in order to promote their objectives, does not necessary mean that political risk does not matter again. On the contrary, recent developments with respect to political risk shows that political risk remains a matter of concern for foreign investors (Russia crisis and Asian crisis).

\footnotetext{
32 Burgmann Todd (1996); An empirical examination of multinational structure, Journal of International Business Studies, 27, p. 553-570.

33 See OECD (1989) study on; International Investment and multinational Enterprises, investment incentives and disincentives. Effects on international Direct Investment, OCDE, Paris 1989, p. 7.
} 


\section{The Management of Political Risk}

Efforts to manage political risk must begin before the investment is made, continue while the investment is negotiated with the host government, extend throughout the investment and operational period, and may be concluded some time after the investment is liquidated or sold. On the corporate level, political risk management is of vital importance in elaborating and implementing responses to political risk problems. In managing the political risk, the multinationals are likely to encounter and to find an efficient method of protecting corporate assets. The management of political risk includes the identification and assessment of political risk, the valuing of political risk, the anticipation of losses, the prevention or reduction of incidences of losses. In an examination and evaluation of the content of political risk management, Margaret Kelly includes the following five steps for managing political risk in foreign investment.

1. The identification and analysis of loss exposure

2. The measurement of losses associated with these risks

3. The development of alternative techniques for treating each exposure

4. The reduction and implementation of the best technique or combination of techniques forecasting each exposure

5. The evaluation of results in an effort to improve the procedures of identification, measurement and treatment. ${ }^{34}$

\section{A. Business responses to political risk; risk avoidance, risk transfer and risk negotiation}

There are two major ways of dealing with political risk at corporate level; risk avoidance, or risk transfer and risk negotiation. The first approach attempts to utilize existing financial, non financial methods and legal arrangements to avoid the risk or transfer it to a third party. Such an approach comprises all the risk assessment methods, all the efforts which aim towards integrating the political risk in capital budgeting as well as all the operating strategies.

The second approach aims to negotiate a favorable deal with the government in question. This comprises mainly the conclusion of BIT's with host countries.

The two major approaches to political risk are not mutually exclusive. In some cases the management can employ the two methods of dealing with political risk as two components of one procedure.

\footnotetext{
${ }^{34}$ Kelly Margaret (1974); Evaluating the Risk of Expropriation, Risk management, January, p. 24.
} 


\section{Political risk assessment}

In his recent examination of political risk as used by North Atlantic multinationals, Frederick Stapenhurst came to the conclusion that a corporation's strategic planning is an important determinant of its profitability and that environment scanning, including political risk assessment is a vital input to this strategic planning process ${ }^{35}$. Indeed a rational approach to the foreign investment decision process requires a careful examination and assessment by the multinationals of numerous factors which relate to both the general political environment of a proposed investment and the specific functions of the firm in that environment. Political risk assessment encompasses the problems of trying to understand and foresee potentially dangerous consequences of future political situations or the potential course of political actions.

There are numerous approaches to the assessment of political risk including event-tree analysis, actuarial techniques or statistical decision theory. For the most part, a mixture of subjective and objective approaches dominates corporate attempts to analyse and assess a country's political climate.

The objective approach attaches importance to methodological and procedural solutions to the assessment of political risk. Proponents of objective approaches therefore views the method and procedure as bulwarks against the fallibility and limitations of human judgment. The objective approach could therefore be also referred to as method or formal-oriented approach. The second approach, known as subjective approach, makes use of human judgment, intuition and experience to predict and forecast the evolution of the political environment. Thus the subjective approached views the human judgment and intuition as a bulwark against the fallibility and limitations of the formal methodology. While methodoriented approaches work on within the context of statistical data and models, the subjective method make intensive use of survey, advice and the judgments of specialists and consultant firms.

The use of a systematic political analysis to forecast and offset political risk is a recent phenomenon. Not so long ago, foreign investment decisions concerning political risk were based first on impressions of managers and dramatic but insignificant political events (political kidnapping or palace coup). Rummel and Heenan refer to it as "the odd-lot syndrome", that is the old tendency-shared by skittish odd-lot investors to be overly influenced by periodic swells of optimism or pessimism and, therefore swing from one potentially costly decision to another by sporadic events. ${ }^{36}$ This is no longer the case. In

${ }^{35}$ Stapenhurst Frederick (1992); Political Risk Analysis around the North Atlantic, New York, St Martin's Press, XIV quoted in Howell Llewelly and Chaddick Brad (1994); Models of Political Risk for foreign Investment and Trade, an assessment of three approaches, Columbia Journal of World Business, Fall 1994, Vol. XXIX, Number 3, p. 70-91, here p. 71.

${ }^{36}$ Rummel R.J. and Heenan David A.; Ibid., p. 68 
this respect Rummel and Heenan point out that "until recently (...) executives could expect only limited help in determining the destiny of their foreign markets. But now, using tool and techniques, once the sole province of economists and corporate planners, decision makers are discovering a variety of ways to assess political risk". ${ }^{37}$

\subsection{Subjective approaches}

Most of the subjective approaches rely on human judgment and experience gained by specialists, businessman, diplomats or experts ${ }^{38}$. The classical subjective approaches to the assessment of political risk includes three methods; the Grand Tours, the old Hands and the Delphi techniques.

\subsubsection{Grand Tours}

The Grand tours method is a particularly old technique, generally based on the general impressions and information gained by the multinationals. These impressions and informations are gathered through some preliminary market research or an inspection tour of the company representatives. The first impressions and information can also be gained through contact with local leaders, government officials and businessmen or through survey of the political landscape for several days by company representatives. All the information and impressions gathered through this short survey of the political landscape are then analyzed and evaluated. Shortcomings of the Grand tour approaches reside in its vague nature and what Rummel and Heenan called an overdose of selective information ${ }^{39}$.

\subsubsection{Old hands}

Through the old hands methods, multinationals seek to acquire area or country expertise from diplomats, journalists, businessman or firm experts on a consulting basis. The expertise of diplomats, journalists or business usually includes assessment of the objectives and personalities of a country's current leadership, the strengths and weaknesses of competing political groups and the likelihood of new legislation ${ }^{40}$. One of the drawbacks of this approach is its unsystematic character and the fact that it is based on the judgments of outsiders. However like Rummel and Heenan points out, the old hands methods can nevertheless provide multinational corporations with an improved understanding of the political dimension. ${ }^{41}$

\footnotetext{
${ }^{37}$ Ibid.

${ }^{38}$ A good overview of subjective Approaches are given in Ibid., pp. 68.

${ }^{39}$ Ibid., p. 69.

${ }^{40}$ Ibid.

${ }^{41}$ Ibid.
} 


\subsubsection{Delphi techniques}

The Delphi techniques offer an example of a more elaborate and systematic use of human judgment and experience. In the first part of the Delphi technique, corporate decision makers try to identify selective elements which could influence a nation's political destiny: size and composition of the armed forces; delays experienced by the foreign investors; political kidnappings etc. Next, a wide range of experts is asked to rank or weigh the importance of these factors for the country under consideration. Then responses are collected and a checklist of the ranked variables is constructed. ${ }^{42}$

Finally, the corporate decision makers aggregate the ranked variables of the checklist into an overall measure or index of political risk ${ }^{43}$

Shortcomings of such an approach involves the possible deficiency of the relevant questions and the fact that a single addition and classification of political variables without taking into consideration other variables such as social, cultural and economic variables is misleading and inaccurate.

To sum up, the main shortcomings of subjective approaches are due, to a large extent to the fact that they rely largely on intuition and human judgment, and therefore also on luck.

\subsection{Objective approaches}

One way to overcome the above mentioned shortcomings of the subjective approaches consists of making intensive use of quantitative data on political factors and of the econometric and probabilistic methods to improve the accuracy, the precision and the predictability of political events. One important objective econometric technique employed for the objective measurement of political risk is for instance multivariate analysis (MVA), which made multidimensional decisions possible. The MVA could provide a very precious source of information for analyzing complex issues such as political risks. Indeed refined quantitative tools for analyzing political risk are gaining favor among decision-makers of multinationals as another way to deal with political risk or of confirming the "intuitive" impressions gained in subjective analysis. The MVA can be classified on the basis of two possible uses: (1)to predict future political trends on the basis of current and historical information or (2) to describe more fully underlying relationships affecting the nation state. ${ }^{44}$ The distinguishing feature of predictive techniques is that one or several variables are said to be a function of some other variables.

\footnotetext{
42 Ibid.

${ }^{43}$ Practical examples of such political Risk index are provided in ibid., p. 70.

${ }^{44}$ Ibid., p. 70.
} 
Multiple regression is in fact one of the predictive techniques used by decision-makers when the data are quantitative or numerical. However, prediction can also involve qualitative or state-of- being information, for example. For those managers not concerned with prediction, descriptive multivariate tool may provide added meaning to a data base through, for instance, cluster analysis or multidimensional sealing.

One of the shortcomings of the quantitative approaches is related to the inherently complex and subjective nature of the political risk. Many important political issues seem to defy quantification, and decision-makers are often forced to rely on their judgment and intuition to a greater degree than may be desirable. Now, most corporate approaches to political risk assessment stress methodological and procedural solutions to the problem of political risk because of its precision and accuracy. Yet as suggested by Strauch, all objective methods work on and within the context of a well defined model ${ }^{45}$. The model is treated as the problem and the problem is identifiable to the model ${ }^{46}$. Results drawn from the model are interpreted as conclusions on the problems itself, assuming that the problem structure matches or comes very close to that of the model. Thus political risk is seen as an objective attribute of the problem to be uncovered, measured and quantified through its counterpart in the model

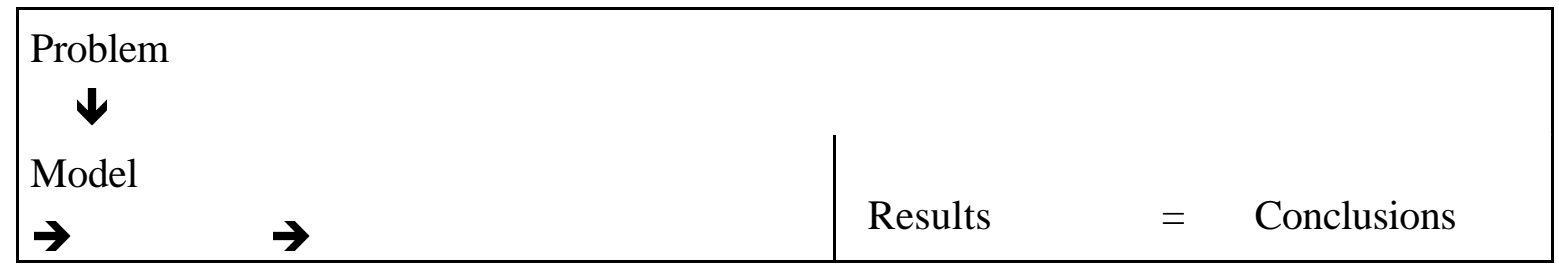

Figure (1)

Source; Strauch, (1980, p. 4)

Moreover, the method-oriented approaches imply conceptually that the decision-maker should play a passive role. He should uncover and bring out what is already inherent in the problem, but is not thought of as playing an active role (like in subjective approaches) in bringing structure to the problem and perceiving and defining the nature of political risk within this structure. According to Strauch, this conceptual role is very much like the one we attach to the scientist; the independent objective who stands separate and apart from the process which he studies and investigates.. ${ }^{47}$ However, this paradigm of model identified with the problem, analyst and objective as an independent observer works, as Strauch points

\footnotetext{
${ }^{45}$ Strauch Ralph (1980); Risk assessment as a subjective Process, The Rand Paper Series ed. by Rand Corporation, March 1980, pp. 4.

${ }^{46}$ For instance see Krayenbuehl Thomas E. (1985); Country Risk Assessment and Monitoring, Cambridge, pp. 33

${ }^{47}$ Ibid; p. 5.
} 
out, only in problems involving well-defined and well- understood systems and processes such as the kind of actuarial risk assessment problems faced by insurance companies but works less well in ill- defined and poorly understood problems ${ }^{48}$. But this is exactly the kind of problem which occurs frequently in assessing the political risk associated with FDI. With this kind of problem, the relationships between the substantive problem and the model ${ }^{49}$ used to analyze is generally more complex (due to the vague nature of political risk definitions) than the characterization depicted in figure 1 suggest.

The substantive problem is therefore likely to differ considerably from the model. There will generally be one or more layers of formulation, simplification and redefinition between problems and modes, necessitating corresponding layers of interpretations between analytical results and substantive conclusion.

\begin{tabular}{|l|c|}
\hline $\begin{array}{l}\text { Squishy Problem } \\
\text { (Political Risk Assessment) }\end{array}$ \\
$\boldsymbol{\downarrow}$
\end{tabular}

Thus the analysis of Strauch suggests a very close link between the quantitative method and human judgment to overcome the drawbacks of method-oriented methods. It is therefore useful to combine quantitative methods with judgment and intuition to generate a more accurate and flexible analysis of the political risk. This could be done through the formulation of an integrated model. This also explains why despite the value of quantitative political risk assessment, many surveys indicate that few multinational corporations have developed systematic approaches for determining the political fortunes of their overseas markets. 50

Rummel develops such an integrated model by combining subjective and objective approaches and therefore providing a systematic framework for both the qualitative and quantitative interpretation of data. Indeed such an integrated model combines both insight

\footnotetext{
48 Ibid.

49 See Rummel R. J and Henan David ; ibid., who refers to political risk as one of the most misunderstood und misinterpreted aspects of multinational operations.

50 Rummel R. J. and Heenan David ; Ibid.,p. 68.
} 
and wisdom with the best features of management science and allows analysts to grasp the most salient aspects of domestic instability, foreign conflict, political and economic climates. ${ }^{51}$

Rummel and Heenan proceed furthermore to provide a concrete case test for the integrated analysis by applying it for the forecast of political events in Indonesia.

Most professional forecasting incorporate the major features of the integrated analysis of Rummel and Heenan in their political risk assessment, through the intensive use of political risk indicators.

\subsection{Political risk indicators}

In recent decades, research on political risk indicators has moved into the centre of economic interest. Stimulated by the theoretical breakthroughs of political models and by the experiences gained by multinationals in their foreign activities, the development of political risk indicators is now one of the most active fields in international finance and in international political economy. Drived by the surge of interest in empirical studies of political indicators, the measures of political instability or political violence, have started to become standard practical variables for the assessment of political risk on the corporate level as well as for explaining cross-country growth regressions in the macroeconomic study of the relationship between economic growth and political variables.

Very different properties of political environment could influences the international investment of a multinational. Thus literature and business use a particularly broad set of political indicators. Two kinds of political indicators are generally used; Firstly, broad political indicators in the sense that they make use of all available political variables of the political system in order to generate a complete political image of a given country. The second kind of political variables stress one political variable, generally democracy, political violence or government stability and generate therefore a partial political image of a given country. Both kinds of political indicators aim to give the corporate manager accurate and precise insights into the political environment of a country. On the other hand, they also have a predictive character in the sense that they also forecast the future political evolution in a given country.

\subsubsection{General political risk indicators}

The use of a general political risk index aims to anticipate changes in government policies and personnel and to provide qualitative evaluation of positions to be taken by opposition parties or groups and by pressure groups. ${ }^{52}$

${ }^{51}$ Rummel R. J and Heenan David ; Ibid., p. 72-76. 
One of the most used general political index is the BERI (Business Risk Service Index) for country risk assessment. In the BERI-index socio-political changes are measured by the Political Risk Index (PRI) and constitute just one part of the country risk assessment. The other parts of the country risk assessment are the Operations Risk Index (ORI), which measure the degree to which complex operating conditions affect profits earned in the local currency by a foreign firm and the R-factor which measures the risk to remittance of profits and repatriation of capital in a convertible currency. ${ }^{53}$

Forecasts of the three measures of risk are then integrated into an overall recommendation, the Profit Opportunity Recommendation (POR). BERI's assessment system also includes qualitative judgments and the quality of these judgments is the foundation for PRI and ORI.

In addition, the approach selected includes the Delphi method which reduces bias and conflict of interests in the results. Results of the three measures serve as parameters for qualitative evaluation as well as assigning the POR rating. 48 countries are regularly monitored by the service and complete scenarios and detailed analysis are available through the forecast service for most of these countries. ${ }^{54}$

Three time periods are involved: +5 years and +10 years. The concept of socio-political assessment (PRI) of the BERI's system utilizes a permanent panel of experts with a political science rather than business. The BERI's sociopolitical assessment (PRI) uses ten elements to list threats to stability; two external causes, six internal causes and two symptoms of political risk.

Six Internal causes of political risk;

- Fractionalization of the political spectrum and the power of these factions.

- Fractionalization by language, ethnic and/or religious groups and the power of these fractions

- Restrictive (coercive) measures require to retain power

- Mentality, including xenophobia, nationalism, corruption, nepotism, willingness to compromise

- Social conditions including population density and wealth distribution

- Organization and strength of forces for a radical left government

Two External causes of political risk

- Dependence on and/or importance to a hostile major power

- Negative influences of regional political forces

52 See Haner F.T with Ewing John (1985); Country Risk Assessment,Theory and Worldwide Practice, Praeger special Studies, USA, p. 50-51.

${ }^{53}$ See the Use Guide BERI SA's Business risk service published in Haner F.T with Ewing John ; Ibid., Appendix B, pp. 283.

${ }^{54}$ Haner F. T with Ewing John ; Ibid., pp 283. 
Two symptoms of political risk

- Societal conflict involving demonstrations, strikes, and street violence

- Instability as perceived by non constitutional changes, assassinations, and guerrilla wars

The measurement of political risk is then developed in four interrelated steps.

In the first step, the political experts rates the present conditions for each of the eight causes shown above from seven (no problem, best case) to zero (prohibitive problems, worst case). Then the two symptoms are rated on the same scale in the present. Thus the function of political experts is to identify major political problems and to assign risk points, that is to place quantitative information in a risk scale. The perspective is from the viewpoint of an international corporation. A theoretical country with no sociopolitical risk has a maximum rating of 70. This is the first subtotal of the BERI system. (ibid. p. 286).

The second step involves the following considerations; One or more of the causes may have a positive impact on the overall political risk. The second subtotal of the system permits discretionary use of 30 points. However because a perfect country rates in reality 100 in the BERI system, the 30 discretionary points are awarded as appropriate to causes of risk that are not a problem in a country. That is, highly stable countries are also rewarded with nonrisk points. Experts typically allocate +20 to a low-risk country, +10 for a moderate risk, and so forth, and usually opt to allocate no additional points to a prohibitively risky country.

The perfect country would receive a rating of 100 as a result of steps 1 and 2 . The third step deals with the forecast of PRI. Steps 1 and 2 are repeated for each of the +5 years and +10 years period. The points awarded to a country under present conditions serve as a basis for changes in the future ${ }^{55}$.

The last step of the construction of a political risk index BERI's system involves the interpretation and judgments of the ratings by sociopolitical experts.

Four categories have become apparent from usage ${ }^{56}$ :

- 70-100; low risk. Political changes will not lead to conditions seriously adverse to business. No major sociopolitical disturbances are expected

- 55-69; Moderate risk. Political changes seriously adverse to business have occurred, but governments in power during the forecast period have a low probability of introducing such changes. Some disturbances will take place.

${ }^{55}$ Haner F.T with Ewing John; Ibid., pp.93.

${ }^{56}$ Ibid. 
- 40-54; High risk. Political developments seriously adverse to business exist or could happen in the near future. Major sociopolitical disturbances are occurring periodically.

- 0-39; Prohibitive risk. Political conditions severely restrict business operations. Loss of assets is possible. Disturbances are part of daily life.

The World Political Risk Forecasts (WPRF) provide another example of an elaborate systematic political risk general indicator. The concept of World Political Risk Forecast was originally conceived by William D. Coplin and Michael K. O'Leary. The construction of the WPRF compared to BERI's System is based on different premises and it uses different methodologies and risk rate system to assess political risk. The WPRF makes intensive use of expert opinion to build up a predictive and accurate political view of a given country. However, the main distinctive feature of the WRPF resides in its risk rate system which is based on the "prince model system". 57

The prince model uses the actors in a political system. Three to five experts estimate the ability of major individuals, groups and institutions to affect political risk in a country. The actors can be domestic and foreign, and they become the potential causes of risk. Each is rated according to (1) disposition-support, neutrality, or opposition, (2) certainty-range of $1-5$, from little or no certainty to extremely high certainty, (3) power-range of 1-5, the latter extremely high power, and (4) salience-range of 1-5, from little importance to opposing/supporting the event/action to extremely high importance. ${ }^{58}$ The combined judgment is then placed on a summary chart for each of the four risk categories. Using regime change as an example, ratings supporting change are recorded as positive numbers and those opposing are recorded as negative. The regime change probability is calculated by the following formula. ${ }^{59}$

Probability $=\mathrm{Ws} / \mathrm{Wt}=$ Sum of positive actors score/sum of absolute value of all actor scores. The probabilities are affected by using 1 as the worst case instead of zero.

Finally there are also a number of country risk evaluations which provide a mixture of economic and political information as well as political risk indicators for the management of political risk. These include, for instance, the reports of "Frost and Sullivan" that provide a mixture of quantitative and qualitative information. In addition, the "International Report" publishes the monthly "International Country Risk Guide", covering approximately 80 countries. On a semi-annual basis "Institutional Investor" also publishes the results of a survey of bankers concerning their subjective rating of debtor countries. However, as Eng,

\footnotetext{
57 Ibid., pp. 97-98.

58 Ibid.

${ }^{59}$ Ibid.
} 
Lees et al. (1998) point out, the two major problems with these country evaluation systems are 1) their reliance on past performance to estimate future prospects. 2) the possibility that isolated events (political or other) will have a strong impact on company operations and profit $^{60}$.

\subsubsection{Partial political risk indicator; the government stability indicator}

Apart from elaborate general political indexes such as BERI and WRPF, an assessment of political risk can also be conducted through the intensive use of partial political indicators. These partial political indicators are characterized by the fact that their scope entails just one part of a political system. Nevertheless their growing use by international organizations and by multinationals to assess political risk shows their importance in the political assessment of countries. Though there exists a variety of partial political indicators, our attention will focus only on government stability indicators because of its wide use by multinationals and in economic literature. Other measures used to evaluate parts of political systems are those assessing democracy, political violence or political volatility ${ }^{61}$.

In addition "Transparency International" (TI), the NGO community's leading corruption fighter makes use of the social unacceptability and media value to generate a corruption indicator. It publishes the annual "Corruption Perceptions Index", which ranks Countries on how corrupt they are perceived to be according to surveys of business people, political analysts, and the public.

Most government stability indicators make use of data gathered in the World Handbook of political and social indicators by Taylor and Jodice (1983) and the cross-national time series data archive updated yearly by Banks(1979) to generate political indicators. Taylor and Hudson (1972). Banks (1979). Measures of actual government stability are clearly more frequent in literature. There are essentially two approaches for deriving indicators of government stability from the data described above. The first is to take the simple period average of such incidents as coups or government changes and the second is to concentrate on the probability of government change by estimating probit regression. ${ }^{62}$ Measures of actual government stability, that is the first method, are used for instance by Roubini (1991), by Grilli, Masciandro and Tabellini (1991). Landau (1986) and Skinner (1987) in contrast use the average number of irregular government transfers as the political variable to rate government stability.

\footnotetext{
60 Eng V. Maximo, Lees Francis A et al (1998); Ibid., p. 428.

61 See Brunetti Aymo (1997); Politics and Economic Growth, a cross-country Perspective, Development Centre of the OECD, OECD, pp. 35.

62 See Brunetti Aymo (1997); Ibid., p. 42.
} 
Other political variables used to evaluate government political stability are the number of revolutions and coups provided by Barro and Wolf (1989).

The second approach for deriving the government political stability concentrates on the probability of government change through probit regressions. This approach is used for instance by Alesina et al (1992) to construct two measures of government instability by estimating probit regressions of government stability.

\section{Monitoring political risk}

One main aspect of political risk management resides in the monitoring of political risk after the decision to proceed with the initial investment has been taken. Since the political environment is changing in nature, i.e. dynamic, the issue becomes how to monitor a dynamic political environment ${ }^{63}$." In a dynamic political environment, factors such as changes, both actual and proposed, in laws or regulations affecting the enterprise, changes in party plattforms, and changes in public opinion, to mention only few must be evaluated. One classical technique to cope with dynamic political changes on the corporate level is provided by Haendel in his book, "Foreign investments and the management of political risk" Haendel describes it as follows; In calculating the net present value of an investment, the analyst deals with expected values and prior probabilities. However, an analyst monitoring additional information may well seek to reflect these changes in terms of probabilities: Bayesian analysis can then be used to revise the prior probabilities on the basis of additional information. ${ }^{64}$

One concrete application of the Bayes's rule to monitor political risk is also provided by Haendel $^{65}$. Let us assume that a company oil uses the Bayes's method in its exploration calculations of drilling for oil. Let us also assume that the chief geologist thinks that the probability of a dry well (D) is 80 percent and the probability of finding oil (O) is 20 percent. The company can obtain more information through seismographic recordings. The evidence will be provided for one of three conditions:

- Event R1: no subsurface structure

- Event R2: open subsurface structure

- Event R3: closed subsurface structure

Past experience reveals that the probabilities of these three events are $0.30,0.36$, and 0.34 , respectively, if there is oil; and $0.68,0.28$, and 0.04 , respectively, if there is no oil. The three possible outcomes of the test will yield a revised probability that there is oil at the site. The

\footnotetext{
63 Haendel Dan; Ibid., p. 125.

64 Haendel Dan ; Ibid., p. 125.

${ }^{65}$ Ibid; pp. 125.
} 
revised probability can then be depicted in form of a decision tree. ${ }^{66}$ Three applications of Bayes's rule are made

$$
\begin{aligned}
& \mathrm{P}(\mathrm{O} / \mathrm{R} 1)=\mathrm{P}(\mathrm{O} \cap \mathrm{R} 1) /(\mathrm{P}(\mathrm{O} \cap \mathrm{R} 1)+\mathrm{P}(\mathrm{D} \cap \mathrm{R} 1))=0.060 /(0.060+0.544)=0.099 \\
& \mathrm{P}(\mathrm{O} / \mathrm{R} 2)=\mathrm{P}(\mathrm{O} \cap \mathrm{R} 2) /(\mathrm{P}(\mathrm{O} \cap \mathrm{R} 2)+\mathrm{P}(\mathrm{D} \cap \mathrm{R} 2))=0.072 /(0.072+0.224)=0.243 \\
& \mathrm{P}(\mathrm{O} / \mathrm{R} 3)=\mathrm{P}(\mathrm{O} \cap \mathrm{R} 3) /(\mathrm{P}(\mathrm{O} \cap \mathrm{R} 3)+\mathrm{P}(\mathrm{D} \cap \mathrm{R} 3))=0.068 /(0.068+0.032)=0.680
\end{aligned}
$$

The first and third outcomes above would have a great effect upon the probability of finding oil. In assessing whether to undertake the exploration, therefore, it was important to find the probabilities of these three outcomes.

The CIA also used the Bayesian analysis as one method of forecasting political events in the Middle East. Schweitzer describes how the CIA processes information by using Bayesian analysis. ${ }^{67}$

\section{Integrating political risk in international capital budgeting}

Foreign investors can account for the political risks of overseas operations in several different ways. Political risk is an important component in the capital budgeting process for foreign direct investment (FDI). Robock (1971), Kobrin (1979), and Brewer (1985) outlined the analytical problems that Roddock (1986) surveyed in his overall study of political risk at corporate level. Sethi and Luther (1986) stressed the problems related to the measurement of a firm's exposure to political risk. Robock (1971), Kobrin (1979), Roddock (1986), Sethi and Luther (1986), Brewer (1991) and recently Clark (1997) raised the issue of integrating political risk into foreign investment theory. Generally speaking, the incorporation of political risk into the capital budgeting process involves two steps. First the risk has to be defined and assessed and, second, the effect of the risk on the investment's outcome has to be measured. ${ }^{68}$

As we have seen earlier, it is very difficult to assess and define political risk. However, whatever the definition of political risk, it is generally recognized that political risk evolves through time in reaction to countless events on the international, national, regional and personal levels. Since many of these events are random in nature, the evolution is at least to some extent random itself.

Once the political risk has been defined and assessed, its effect on the investment's outcome must be measured. One of the most used method to reflect the higher perceived political risk

\footnotetext{
66 Ibid.

67 Schweitzer Nicolas (1976); Bayesian analysis for Intelligence; Some Focus on the Middle East, Paper delivered at the international Studies Association Meeting, Toronto, Canada, February 1976 cited in Dan Haendel; Ibid., p. 126-128.

68 See Clark Ephraim (1997); Valuing political Risk, Journal of International Money and Finance, Vol 16, Nr 3, P. 477-490, here p. 478
} 
in the capital budgeting process is to raise the discount rate for foreign investments. ${ }^{69}$ For instance, if exchange restrictions are anticipated, a normal require return of $15 \%$ might be raised to $20 \%$.

The use of a shorter pay-back period fulfills the same function, for example if exchange restrictions are anticipated, a five-year pay-back period may be shortened to three years. However, both methods cannot provide a detailed examination of the political risk involved or a true reflection of the investor's fear. ${ }^{70}$ Moreover, neither of the aforementioned approaches lend themselves to a careful evaluation of the actual impact of a particular risk on investment returns. ${ }^{71}$

Because thorough political risk analysis also requires an assessment of the magnitude and timing of political risks and their implications for the projected cash flows, new accurate methods have been developed to measure the effects of political risk on investment's outcomes. Based on the work of Stonehill and Nathanson (1968), Shapiro (1978), Stobaugh(1969), and recently on the works of Clark (1997), Mahajan (1990) and Buckley (1996) regarding international capital budgeting for FDI, integrating political risk assessment into capital budgeting process can generally be broken down into three approaches.

The first approach, used for instance by Shapiro (1978), involves adjusting the project's expected future cash flows to account for losses due to political risk. Buckley's (1996) approach can be considered in fact as just a refinement of Shapiro's approach in the sense that Buckley tries to draw from Shapiro's approach a generalized formula for assessment of political risk in investment appraisal.

The second approach, propounded by Clark (1997), involves measuring the effects of political risk on the outcome of a foreign direct investment as the value of an insurance policy that reimburses all losses resulting from the political event or events in question and therefore incorporating explicitly the stochastic and evolutionary aspect of political risk as well as the timing of political events into the valuation of political risk.

The last approach, propounded by Mahajan (1990) makes use of option valuation theory to derive the pricing of political risk and specifically of expropriation risk. The rationale behind this last approach is that while standard valuation procedures like adjusting future cash flows are adequate when the probability of expropriation is independent of a project's value, if the

\footnotetext{
${ }^{69}$ See Shapiro Alan C (1992); Multinational financial Management, 4ed., USA, p. 450.

70 Haendel Dan; Ibid., p. 128.

${ }^{71}$ Shapiro Alan C (1992); Ibid., p. 453.
} 
likelihood of expropriation depends on project outcomes, the only appropriate valuation technique is contingent claims analysis.

The issue to be discussed in this chapter is how the political risk, as it was defined and assessed earlier, should be integrated into the process of the capital budgeting. This is a normative question which deals with what should be done. Political factors have an important effect on the variability of the cash flows of many investment projects. These factors are often ignored and not reflected in the current procedures of capital budgeting. In this chapter the political factors are defined in a measurable way, and their effect on the cash-flows of any given investment project is evaluated. In this way, political risk becomes an explicit part of the procedure of capital budgeting.In order to integrate considerations of political risk into the procedure of capital budgeting, a normative, operational model is needed.

Before beginning with the examination of some models for integration of political risk into capital budgeting, it is useful to first of all comprehend and grasp the philosophy and logic lying behind the process of translation of political risk evaluation into a practical procedure. This will be done through the presentation of a simple and telling operational Model of Agmon (1985).

\section{1. Understanding the process of integrating Political Risk into Capital budgeting: An Operational Model}

Agmon (1985) has proposed a workable and comprehensive way to integrate political risk into capital budgeting. Because of its simplicity, its explanation power and its fecundity, the model developed by Agmon (1985) will be utilized in the present chapter as a general introduction to the integration of political risk into capital budgeting process, as it provides useful insights into the process of integration of political risk into capital budgeting and highlights the principles and philosophy lying behind the translation of political risk evaluation into a practical procedure. Moreover, it comprises most assumptions on which the recently proposed models of integrating political risk are made, that is, it provides a basis for the operationalization of political risk in recent models. The model of Tamir Agmon relies on the following premises.

The potential dependence of a project on its external political environment is divided into two components; vulnerability and cost. Vulnerability is expressed by the probability that a political event that has an effect on the project will occur. In this way vulnerability is not defined in terms of joint probability. Rather, vulnerability is defined in terms of events. Examples are changes in tax regimes or change in the regulatory structure. Vulnerability is 
also defined as a probability distribution and for simplicity it is assumed that the distribution can be fully described by its expected value and its variance. Thus, an event can be described by these two parameters. For example, management can estimate the expected value of the impositions of import restrictions within the next two years as 60 percent. The variance around this estimate is a measure of the reliability of this estimate.

Cost in Agmon's model as the actual impact on the cash-flows of a given project if a given political contingency occurs. For example, the imposition of price control for a period of two years will reduce the net present value of the project under consideration by \$1million. This is a simplistic example where all the necessary information is available. Normally there is limited historical experience with regard to political events, and translating political contingencies to net present values is problematic at best. Therefore cost is also expressed in probabilistic terms.

Political dependence is a function of vulnerability and cost and it is assumed that vulnerability and cost are independent of each other- that is, there is no necessary relationship between the likelihood of occurrence of a given event a likelihood that is determined on a macro, political level, and its cost implications to a certain investment project. For example, while the government is attempting to select an effective regulatory policy to carry out some social goals, its objective is modification of behaviour and not changing the viability of a specific project. The political dependence of investment projects can be analyzed with the aid of the following two-by-two matrix in the form of a reduced "prisoner dilemma".

\begin{tabular}{c|c|c|}
\multicolumn{1}{c|}{ High } & \multicolumn{1}{c|}{ Vulnerability } \\
\cline { 2 - 4 } High & $\begin{array}{l}\text { Political risk } \\
\text { is important }\end{array}$ & Pow \\
\cline { 2 - 3 } & & Political risk \\
Low & can be ignored \\
\hline
\end{tabular}

Source; Agmon (1985, p. 60-61)

The Agmon's political dependence matrix 
This political dependence matrix can be interpreted as follows: The implications along the left/right diagonal are clear. Firms will be concerned only minimally with low-vulnerability, low-cost situations. All firms should be concerned with a situation of high vulnerability and high cost. Interpretation of the two other cells is more ambiguous. In general, managers will be more concerned with situations of low vulnerability and high cost rather than with situations with high vulnerability and low cost.

The distinction between vulnerability and cost is critical to the analysis. Firms and managers need not be concerned with all possible political events. Indeed, most political events do not have much of an impact on the cash-flows of a specific project. Those events that have a non-trivial effect on the cash-flows have to be weighted by their probability of taking place. $^{72}$

In summary, political dependence is a multiplicative function of vulnerability and cost where $\mathrm{Di}=\mathrm{Ei} \mathrm{Ci} \quad \mathrm{i}=1 \ldots, \mathrm{N}$ political events

Ei is the probability of a given event $\mathrm{i}$. Ci the cost associated with this event. Di is a measure of the dependence with respect to a given political event.

Making the estimation of political risk work for the purposes of capital budgeting requires the ability to define and quantify the following:

1. The probability distributions of possible political events; and

2. The probability distributions of impacts on the present value of any given project

3. An estimate of the vulnerability and the cost for any project on a period by period

The following five steps present a concrete way to integrate political risk into the process of capital budgeting.

\section{Enumerate Potentially Significant Contingencies}

Contingencies are defined in terms of impact on cash-flows and on projects rather than environmental events. Developing a list of possible contingencies requires an ability to identify the critical inputs and outputs for the project under consideration, the external groups that have the ability to control or otherwise constraint the current and future flows of these critical inputs and outputs. Possible methodologies to accomplish this ability include scenario analysis, issue analysis, and actor-based analysis. Enumerating contingencies also requires a thorough knowledge of the project and political environment. The base to all analysis should be the estimate of the project's cash-flows over time.

\footnotetext{
72 Agmon Tamir ; Ibid., p. 60-61.
} 
2. Narrow the List to a Feasible Set of Contingencies

The list of contingencies developed in step 1 has to be pruned down to a workable number, maybe ten to fifteen. The criterion to choose which event to include is the potential effect on the net present value of the project.

\section{Estimate Vulnerability for Each Event over time}

This part of analysis examines the probability that a given event, taken from the "short list", will occur in any time period during the duration of the project. Given that it has taken place in a given period, what are the implications for the project? for example, should it be abandoned, redesigned, or perhaps left as it is?

4. Compute the Probability Distribution of the Cost Associated with the events

In this step the probability distributions of the costs to the project as a function of the political events are computed. The cost is expressed in terms of an expected value and a standard deviation

\section{Estimate Dependence as Function of Vulnerability and Cost}

In this last step the dependence function is estimated for the project as a whole. In this way, political dependence is quantified as a part of the standard cash-flows analysis. Sensitivity analysis can be utilized if the basic information on the likelihood of political event is scant ${ }^{73}$.

\subsection{The Approach of Shapiro (Adjusting cash flows)}

Because there is more and better information on the specific impact of a given risk on a project's cash flows than on its required return, for Shapiro the recommended approach for taking into account the political risk should consist of adjusting the cash flows through the use of "expected values". ${ }^{74}$ The following assumptions are made in the Shapiro model for valuing political risk.

- The cash-flow adjustments employ only expected values, that is, the analysis reflects only the first moment of the probability distribution of the impact of a given risk

- While the procedure employed by Shapiro does not assume that shareholders are risk neutral, it does assume either that risks such as expropriation, currency controls, inflation, and exchange rate changes are unsystematic or that foreign investments tend to lower a firm's systematic risk.

From these assumptions made by Shapiro, the general approach for incorporating political risk in an investment analysis involves adjusting the cash flows of the project (rather than its

\footnotetext{
73 Agmon Tamir; Ibid. pp 60.

${ }^{74}$ Shapiro Alan C (1992); Ibid., p 453.
} 
required rate of return) to reflect the impact of a particular political event on the present value of the project to the parent. ${ }^{75}$

Shapiro provides a case example how these cash flow adjustments can be made for the cases of expropriation, that is, how adjusting expected cash flows can be used to analyze the effects of expropriation. The approach suggested here examines directly the impact of expropriation on the present value of the project to the parent.

\begin{tabular}{|l|l|l|l|}
\hline & Expropriation & No expropriation & Expected Present Value \\
\hline Sell out now & 128 & 128 & 128 \\
\hline Wait & 100 & 300 & $(100 \mathrm{p}+300(1-\mathrm{p})) / 1.22$ \\
\hline
\end{tabular}

Source; Shapiro (1992, p. 468)

Suppose that a multinational enterprise illustrated here by United Fruit Company (UFC) is worried that its banana plantation in Honduras will be expropriated during the next 12 Months. The Honduran government has promised, however, that compensation of $\$ 100$ million will be paid at the year's end if the plantation is expropriated. UFC believes that this promise would be kept. If expropriation does not occur this year, it will not occur anytime in the foreseeable future. The plantation is expected to be worth $\$ 300$ million at the end of the year. A wealthy Honduran has just offered UFC \$128 million for the plantation. If UFC's risk-adjusted discount rate is $22 \%$, what is the probability of expropriation at which UFC is just indifferent between selling now or holding onto its plantation? ${ }^{76}$

The above example displays UFC's two choices and their consequences. If UFC sells out now, it will receive $\$ 128$ million today. Alternatively, if it chooses to hold onto the plantation, its property will be worth $\$ 300$ million if expropriation doesn't occur and worth only 100 million in the event the Honduran government expropriates its plantation and compensates UFC. If the probability of expropriation is $\mathrm{p}$, then the expected end-of-year value of the plantation to UFC (in millions of dollars) is $100 p+300(1-p)=300-200 p$. The present value of the amount, using UFC's discount rate of $22 \%$, is (300-200p)/1.22. Setting this equal to the $\$ 128$ million offer by the wealthy Honduran yields a value of $\mathrm{p}=72 \%$. In other words, if the probability of expropriation is at least $72 \%$, UFC should sell out now for $\$ 128$ million. If the probability of expropriation is less than $72 \%$, it would be more worthwhile for UFC to hold on to its plantation. ${ }^{77}$

\footnotetext{
75 Shapiro alan C (1992); Ibid., p. 467.

76 Shapiro Alan C (1992); Ibid., p. 468.

77 Ibid.
} 
In this example of Shapiro, the economic outcomes can be regrouped in three mutually exclusive scenarios. Either the plantation is not expropriated or it is expropriated with compensation or the plantation is sold before the expropriation. When these scenarios are matched with cash flow estimates, expected cash flows can then be estimated. The values obtained in this way can then be multiplied by the probabilities of each outcome, to obtain an expected value. One shortcoming of the Shapiro's approach resides in the fact that assigning probabilities to scenarios is very difficult. ${ }^{78}$

Further recent developments or refinements of the Shapiro approach can be seen in Buckley`s attempt to derive from the Shapiro approach a generalized formula for assessment of political risk in investment appraisal. The basic argument of Buckley's approach is developed by looking at the effects on project outcomes of number of political risk events namely expropriation, blocked funds and increased taxes. The results obtained by Buckley can be summarized as follows: Political risk in international capital budgeting is best taken into account at the ex ante stage by the break-even probability approach. This involves estimating the probability of occurrence of a particular political risk factor such that the present value of the project moves from being positive to being zero. The generalized formula for the break-even probability always equals:

NPV of investment (base case)/Present value of forgone cash flows following implementation of political risk factor. That is, political risk can be allowed for by dividing the net present value by the present value of forgone cash flows following implementation of political risk factor ${ }^{79}$.

\subsection{The Approach of Clark Ephraim}

In his paper (Valuing political risk) Ephraim, Clark (1997)develops an approach to measuring the effect of political risk on the outcome of foreign direct investment that explicitly defines the evolutionary process of political risk and incorporates the stochastic elements in its evolution as well as the timing of the political events that generates losses.

Clark's approach involves measuring the effects of political risk on the outcome of a foreign direct investment as the value of an insurance policy that reimburses all losses resulting from the political event or events in question.

\footnotetext{
78 The Differences in the Methods used to integrate political Risk with financial Risk Analysis are best illustrated by one example provided by Haendel Dan; Ibid., p. 128-130

${ }^{79}$ Buckley Adrian (1996); Multinational Finance, 3rd ed. Great Britain, p. 413-419. For algebraic demonstrations see Ibid.
} 
In the model developed by Clark, political risk is defined as the probability of politically motivated change that affects the outcomes of foreign direct investment whereby a distinction is made between explicit events and ongoing change. Explicit events take the form of legislation or decrees such as expropriations, nationalizations, devaluations, etc. or the form of direct actions such as strikes, boycotts, terrorist acts, etc. The nature of explicit events is that they arrive intermittently at discrete intervals and that they generate an actual loss. Explicit events are represented in the Clarke's model by a Poisson jump process.

In contrast to explicit political events, ongoing change takes the form of continuous activity such as macroeconomic management and monetary policy, legislation, or social and political evolution that affects some or all aspects of the FDI's overall environment.

In Clark's model, ongoing change impacts on the level of what can be lost in the case of an explicit event and is represented by geometric Brownian motion. An example of the distinction between explicit events and ongoing change is provided by Clark in the form of an over-expansive monetary policy with a fixed exchange rate. The over-expansive monetary policy generates the ongoing changes that affect what will be lost if the explicit event of a devaluation takes place. On the other hand, with a floating exchange rate, changes in the value of the host country's currency would be considered ongoing change and not an explicit event.

To apply the Clark's model, political risk must first of all be defined in terms of the explicit loss generating event or events that the policy is designed to insure against. Once this has been done, the probability of the event actually occurring must be estimated. Any of the proven techniques for assessing political risk can be useful in this endeavor, although the econometric techniques might be the most effective in practice. The next step is to measure the current level of the country's political volatility relative to the investment. Again, any of the proven techniques can be useful. For example, historical volatility of the country's GDP could be measured directly. The last step involves estimating the country's political risk intensity parameter.

Once the current level of exposure to political risk has been estimated, the model can be applied to obtain the cost of the political risk. The procedure for incorporating this cost into the capital budgeting process involves estimating the project's NPV or APV as if there were no political risk and then subtracting the cost estimate of political risk obtained from the mode.

To sum up, Clark presents an approach for measuring the effect of political risk on the outcome of FDI projects where political risk is defined as the probability of politically 
motivated change that affects the outcome of FDI and the distinction is made between explicit events and ongoing change.

The nature of explicit events is that they arrive intermittently at discrete intervals and they generate an actual loss. Explicit events can be represented by a Poisson jump process. Ongoing change takes the form of continuous activity that affects some or all aspects of the FDI's overall environment and can be represented by geometric Brownian motion. Using the combination of geometric Brownian motion and Poisson jumps, the effects of political risk on the outcome of a foreign direct investment project are measured as the value of an insurance policy that reimburses all losses resulting from the political event or events in question. ${ }^{80}$

Although the model developed by Clark seems more realistic in the sense that it reflects the stochastic, evolutionary and changing nature of political risk. Clarke's model is however based on certain doubtful premises which reduce the theoretical and practical significance of the model. While political risk may represent a good opportunity as well as a cost for the foreign investor, valued in the Clark's way, political risk enters the capital budgeting process directly only as cost. That is, Clarke's model envisages political risk only as cost for foreign investors so that it is not very useful in the investigation of gains a foreign investor can win through political risk.

Another shortcoming of Clark's model resides in the fact that most parameters used, that is the rate of growth of political intensity, the rate of growth of the value of the investment, the level of the political risk associated with variations in the performance of the economy and the mean arrival rate of explicit loss generating political events are all dependent directly or indirectly on an accurate assessment and definition of political risk. This means that the quality of results obtained from Clark's model are dependent on the definition of political risk which in turn is very controversial and subjective.

\subsection{The Approach of Mahajan}

Mahajan, using the theory of option valuation tries to derive a model for pricing expropriation risk of a foreign project and to show how this risk can be incorporated in a multinational corporation's asset selection decision. Furthermore, the proposed framework can be used also to determine a multinational corporation's optimal value-maximizing strategy to manage this risk. In the Mahajan's framework, the act of expropriation by the host country is analogous to it exercising a call option on a multinational corporation's foreign direct investment. The well-established theory of option valuation is thereby linked

\footnotetext{
${ }^{80}$ For algebraic demonstration see Clark Ephraim; Ibid.
} 
with the pricing of expropriation risk. A pricing model is developed and shown to have direct application for a multinational corporation's capital budgeting, and provides an economic rationale for the observed behavior and strategies of multinational corporations in managing their expropriation risk. A three-step approach to capital budgeting is suggested when the multinational corporation faces a risk of expropriation. In the first step, the parent should assume a zero probability of expropriation and compute the project's NPV using the following equation;

$\mathrm{NPV}=\left[\sum_{j=1}^{N} \sum_{i=1}^{T} \frac{C F_{j, t}}{(1+k)^{t}}\right]-I$

Where the Project's aggregate expected cash flows to the multinational corporation spanning a $\mathrm{T}$-year time horizon ( $\mathrm{t}=1$ to $\mathrm{T}$ ) are unbundled into $\mathrm{N}$ separate component flows $\left(C F_{j, t} C F_{j, t}, \mathrm{j}=1\right.$ to $\left.\mathrm{N}\right)$, each with its own distinct discount rate $\left(k_{j}\right) . I$ is the present Value of the outlay required to undertake the project.

Project cash flows in this step should be associated with the initial optimal strategy regarding transfer pricing, fee and royalties, currency denomination, and the sourcing of inputs and outputs, taxes, capital structure, and other such value-enhancing possibilities available to the corporation. In step two, the multinational corporation should price the risk of expropriation of the project. (i.e. determine $\mathrm{C}$ ) using the following equation

$$
C=S N\left[\frac{\frac{S}{X}+\left[r_{h}-\alpha_{x}+\frac{\sigma^{2}}{2}\right] T}{\sigma \sqrt{T}}\right]-X_{e-\left(r_{h-\alpha_{x}}\right)^{T}} \times N\left[\frac{\ln \frac{S}{X}+\left[r_{h}-\alpha_{x}-\frac{\sigma^{2}}{2}\right] T}{\sigma \sqrt{T}}\right]
$$

where $\mathrm{S}$ is the current value of the MNC's investment in the foreign project; $\sigma^{2}=\sigma_{s}^{2}-2 \rho_{s x} \sigma_{s} \sigma_{x}+\sigma_{x}^{2} ; \rho_{s x}$ is the instantaneous correlation coefficient of $\mathrm{S}$ and $\mathrm{X}$ (i.e. $d z_{s} d z_{x}=\rho_{s x} d t$ ); and $\mathrm{N}($.$) is the cumulative normal distribution function and initial \mathrm{t}=0 .{ }^{8}$ given the above strategy.

Step three will entails utilizing equation $\mathrm{NPV}^{*}=\mathrm{NPV}-\mathrm{C}$ where $\mathrm{C}$ represents the present value of the expropriation risk faced by the project, to calculate NPV, the project's expropriation risk-adjusted net present value. If this is positive, the asset selection rule will be to accept this project. 81

${ }^{81}$ Mahajan Arvind (1990); Pricing Expropriation Risk, Financial Management, winter 1990, p. 77-86 
4. Understanding and monitoring conflicts between host countries and investing firms; The obsolescing bargain theory

Monitoring political risk also means explaining the nature of the relationship between the host countries and investing firms and from there try to derive the attitude and policy to be adopted to manage political risks. From this point of view, Foreign direct investment decisions are seen as a result of negotiations between host countries and foreign firms, whereby multinationals and foreign firms, trying both to increase and augment their bargaining powers in order to gain advantages and offset their own risks. One way to understand the nature of relations between host countries and investing firms is provided by the "obsolescing bargain" theory as propounded mainly by Vernon (1968). The theory of obsolescing bargain essentially reflects the concerns of foreign investors in developing countries over the possibility that government policies may easily change ex post in ways that take away or redistribute the quasi-rents to FDI assets. This theory is based on the following premises:

1. Investing firms and host countries pursue diverging interests. This results in a latent permanent conflict between LDCs and investors

2. Investing firms and host countries (LDCs) exchange information through dialogue

3. Investing firms and host countries negotiate the initial terms of FDI entry as well as a variety of operational issues on intermittent basis.

4. FDI presents problems of credibility and commitment that do not arise with domestic investment. Once a firm builds a plant in a foreign country, the plant becomes a potential hostage to the host country government.

This problem, in which the relative bargaining power of the country and the firm change systematically over the life of the agreement, has been referred to as the "obsolescing bargain".

Following these assumptions, a vast literature on FDI were developed in economic literature concerning the bargaining relations between investing firms and host governments. The biggest strand of this literature concerns the obsolescing bargain explanation of expropriation, For instance Bergsten, Horst and Moran (1978) and Vernon (1971).

In addition there are a large number of case studies and more theoretically-oriented studies as well that have analyzed the issues and behavior in such bargaining processes (e.g. Weiss, E (1990).

A variety of considerations suggested that the bargaining position of host countries is generally strengthening in relations to foreign investors. One explanation resides in the informational asymmetry between the investors and the host countries since host countries are supposed to have access to all information needed by foreign investors. 
In accordance with the bargaining nature of relationships between the host countries and investor firms and with regard to the weak bargaining position of investors many economic models have then proposed many ways to improve and strengthen the position of the investing firms in the bargaining process, with the aim of reducing and managing efficiently the effects of political risks and in particular of expropriation risks. At the same time these economic models seek to understand the logic and philosophy underlying the behavior and attitude of host government towards FDI and on the other hand to design more effective FDI policies. Most models proposed in this framework build on a number of studies which examined the FDI under threat of explicit or implicit expropriation (e.g. Doyle and Van Wijnbergen (1984), Samuelson (1986, 1989), Raff (1991), Brander and Spencer (1987), Thomas and Worrall (1990).

Earlier studies based on the theory of obsolescing bargaining have shown that if one assumes strong reputational effects- that is when the host government is concerned about its reputation in the international business community, restricted form of taxation and some bargaining power on the part of MNCs-, the problem of expropriation risks may be alleviated or reduced. (Veugelers 1993). This may especially help in countries where a great deal of foreign investment is flowing in and the government expects to lose substantial benefits from future FDI if he takes adverse actions against existing foreign enterprises. However as Yongsae and Haidi (1998) show, in most LDCs where FDI has remained limited, the reputational concerns may not be very strong. Moreover, loss of reputation depends on the verifiability of government and MNCs actions by third parties. But the details of Government-MNCs agreements and the actions that constitute agreement violation are rarely public information. However Yongsae and Haidi (1998) have proved that even in the presence of a few reputational guarantees FDI may be feasible if the match between the MNCs and host country can generate a surplus.

When match-specific returns are large, the possibility that the MNCs may lose its incentive to apply its specific assets to the projects can discourage the government from expropriating the MNCs quasi-rents. This allows those MNCs with assets that are good matches for a country's conditions to carry out some investment even if the country's policy risk for FDI is generally high.

\section{B. International Institutions and management of political risk}

Many international attempts were made to cope up with political risk especially in third world countries. Most of the multilateral attempts made at international level were conducted (under the auspices)by the World Bank and OECD which has been active in the investment policy area since 1956. This process of institutionalization of international 
investment framework constitute the foundation for the establishment of an international investment law. Four ways were envisaged, especially by the World Bank and OEDC, to reduce or offset the political risk in the developing countries. The first way includes all measures which aim to influence the host government investment policies. The second range of measures deals with the creation and set up of a new multilateral insurance agency for political risks. The third way consists of the creation of an organization for arbitration and conciliation of investment disputes. Finally the World Bank and OECD try to reduce the influence of political risks on FDI by extending the rules of WTO to the domain of investment. These rules include the transparency of investment rules, the application of the concept of most-favored nations as well as the application of national treatment in the investment area. In addition, to improve the policy framework for FDI and reduce political risk, bilateral agreements were implemented.

\section{The World Bank Group}

The World Bank has now three agencies working in this field: the international Finance Corporation, the International Centre for the Settlement of Investment Disputes, and the Multinational investment Guarantee Agency.

\subsection{The International Finance Corporation}

The International Finance Corporation (IFC), which is affiliated to the World Bank, began operations in 1956. Its objective is to promote economic development in third world countries through support of the private sector. The IFC provides private business with equity and loans without governments guarantees. The organization also provides technical assistance and recently began to offer advice on policies and institutions that should be established to attract and regulate foreign investment.

The investment promotion activities of the IFC include an advisory service on policies and institutions that can assist members in attracting and regulating foreign investment. The advisory service program will assist developing countries in formulating:

- general strategies toward foreign direct investors

- policies to attract investment in specific sectors

- strategies to promote foreign investment

- policies on technology transfer

- ways of increasing the effectiveness of government institutions dealing with foreign investors. 
Other investment promotion strategies of the IFC include:

- identification of firms in developed countries that are interested in developing country investments

- identification of investment opportunities in developing countries

- direct marketing to increase business awareness of IFC programs

- development and promotion of investment opportunities

- development of "new financial products and services that will meet the needs of industrial country investors 82

\section{2. The international Centre for Settlement of investment Disputes}

Another World Bank affiliate, the International Centre for the Settlement of Investment Disputes (ICSID), was created in 1965. Its key objective is to assist in the conciliation and arbitration of investment disputes between member states and nationals of other member states. Ninety-seven states have signed and eighty-nine states have ratified the Convention establishing ICSID. 83

From its founding in 1965 to 1987, twenty-three cases have been submitted to the Centre, fourteen of which has arisen since $1981 .{ }^{84}$ There are certain prerequisites for submitting a case to ICSID. A dispute must be between a contracting state and a national of another contracting state. The parties must agree to ICSID conciliation or arbitration through a clause in an investment agreement or by agreeing to submit an existing dispute to the Centre. Agreement to settle the dispute cannot be unilaterally withdrawn. The dispute must be legal, not commercial. Investment is not defined and subjects such as loans and industrial property are included in the notion of investment. ICSID arbitration is especially significant in that the parties are bound by the awards. Contracting states must recognize and enforce the pecuniary obligations imposed by the award as if they were a final judgment of a court of the state involved.

\subsection{The MIGA; (The multilateral Investment Guarantee Agency)}

The political risks mentioned above can be lumped into two categories: those largely beyond and those within the control of the host government. In the former one could place war, insurgency and severe political instability. Government policies would predominate in the other. Industrialized countries, multinationals and international organizations have

82 Guertin L. Donald (1990); A program Leading to an international agreement on Foreign Direct Investment in; Foreign Direct Investment in the 1990s, a new climate in the third World, ed by Wallace Day Cynthia and contibutors, Kluwer academic Publishers 1990, The Netherlands, p. 130-131.

83 See News from ICSID, June 30, 1997.

${ }^{84}$ See News from ICSID (Winter 1987) and ICSID Cases, 1972-1987. 
attempted to neutralize the first category of political risks faced by multinationals by providing insurance to cover political risks. That is the rationale for the Multilateral Investment Guarantee Agency (MIGA). ${ }^{85}$

The proposal for a Multilateral Investment Guarantee Agency (MIGA) was launched at the Seoul, Korea meetings of the World Bank and International Monetary Fund in 1985, although unsuccessful plans for similar agencies go back a number of years. Basically a multilateral investment insurance, MIGA have the primary function of insuring foreign investors in developing countries against political risks. At the urging of the United States and other developed countries, MIGA's Charter contains an explicit mandate of encouraging economic policy reform in recipient countries. The United States ratified the MIGA Charter in April 1998, and this member agency of the World Bank group became operational in July 1988 as the first global agency to insure Foreign investment against political risks.

In April 1988, 63 countries had signed and 31 countries had ratified the agreement. These 31 countries account for 54 percent of MIGA's authorized capital of $\$ 1.1$ billion $^{86}$. Since 1985, the use of MIGA has been growing. For e.g., the agency signed 54 guarantee contracts in 1995, compared to 39 in $1994^{87}$. Moran(1986, p. 13) has estimated that even under optimistic assumptions, the additional investment likely to take place because of the availability of MIGA insurance is likely to be quite modest-perhaps no more than $\$ 200$ million. However, as Clarke N. Hills (1990, p.15) points out, even if Moran is correct, his estimate does not take into account the hoped-for beneficial effect on host government policies. MIGA has two principal roles: providing guarantees against non commercial risks; and working to improve investment conditions and promoting investment in developing countries. The guarantee program covers four types of non-commercial risk:

1) restrictions on currency conversion and transfer

2) expropriation, including creeping expropriation (actions by governments which, in effect, deprive the foreign investor of ownership or control)

3) breach of contract in cases where a foreign investor has no access or lacks timely access to a judicial hearing or arbitration

4) armed conflict or civil disturbance.

Furthermore the MIGA provide the following assistance to host countries desiring assistance in attracting foreign direct investment:

\footnotetext{
${ }^{85}$ See Voss J (1987); The multilateral Investment Guarantee Agency, status, Mandate, Concept, Features, Implicatins, Journal of World Trade Law, August 1987.

${ }^{86}$ See Guertin , Donald L; Ibid., p. 132.

87 Eng V. Maximo, Lees Francis et al; Ibid., p. 429.
} 
- research

- dissemination of information on investment opportunities and the climate for investment in host countries

- technical assistance, when requested by members, regarding investment, promotion and policies to attend foreign investment

- policy guidance and advice regarding investment agreements relating to MIGA's role as guarantor of an investment.

\section{Multilateral Agreements}

Various mechanisms operating at the multilateral level between states are in operation or proposed, in an effort to alleviate concerns about investment security and political risk. First and foremost we have proposals to develop multilateral rules of the game for international investment. Four essential ingredients can help to understand the reviving work on an international investment agreement. These include:

An increased number of host countries having a more significant stake in such an agreement; a more positive attitude toward FDI by many home countries since the late 1980s; a body of agreements in particular bilateral treaties on FDI; and an institution which could serve as an acceptable forum in which to develop an international investment agreement, viz., the World Bank. The recent and more important proposal of this kind is the Multilateral Agreement on investment (MAI) now being negotiated at the OECD.

Given that investment flows- as seen in previous chapter- have increased so rapidly in the last decade, one might ask why an MAI is necessary. The answer is that because of unevenness of investment regimes, foreign investment now flows to relatively few countriesespecially developing countries-. An MAI could create new opportunities for capital exporters and importers. An MAI address a number of issues, each of which reflects the obstacles faced by investors in foreign markets. The first is basic market access and deals with restrictions that inhibit an investor's right to establish in a particular jurisdiction. These can include among others, outright or sector-specific prohibition on FDI, or rules that specify ownership restrictions, local control over decision-making or performance requirements in return for admission to the market. Because they are often part of national development programs in all countries, such investment restrictions are unlikely to be banned completely in a MAI.

The goal of the ongoing OECD negotiations on MAI is to create a strong and comprehensive multilateral legal framework for foreign direct investment (FDI) among the OECD's countries. The MAI will reduce barriers to FDI and increase legal security for 
international investors. It will seek to "level the playing field" by providing for national treatment-that is, by ensuring that foreign investors would receive the same treatment and advantages as domestic companies. To give teeth to the MAI, the intention is that it will be legally binding and contain effective provisions for settling disputes. It will, moreover, be a free-standing treaty open to all the OECD countries and the European Union (EU), and to accession by non-OECD countries. The OECD countries have co-operated for many years on investment matters on the basis of a framework of OECD investment instruments-the Declaration and Decisions on International Investment and Multinational Enterprises and the Codes of liberalization of capital Movements and of Current Invisible Transactions. ${ }^{88}$

Apart from the MAI, international attempts were also made to promote a multinational commitment with regard to the substance of investor protection, i.e., a promise not to take without paying or not to repudiate contracts without cause. There were a series of resolutions by the United Nations General Assembly that were promoted as providing assurances and clarifying the rules of customary international investment law. The 1962 resolution was hailed by industrial countries as meeting their needs for security. It was followed in 1974 by another resolution, the Charter of Economic Rights and Duties of States, which seemed to lead out of the field any commitment to a supranational standard of compensation, leaving it to the state doing the taking to decide what it could and would afford.

Given the growing impracticability of isolating national economies from each other, and the obvious linkages and in some cases substitutions, of investment for trade, it is not enough to have an international trade regime, the GATT, without a counterpart for investment. Thus efforts also are being made to initiate multilateral negotiations on investment matters among a large number of developed and developing countries within the WTO. Some progress was made in this direction in the Uruguay round, with the negotiation of the three agreements on trade-related investment measures (TRIMS), trade in services, and trade-related aspects of intellectual property rights, which limit aspects of host-country policies towards FDI that would adversely affect international trade.

The North American Free Trade Agreement (NAFTA) treaty is another example of regional treaty between developed and developing countries. Like some of BITs, this treaty enumerates investment liberalization objectives and establishes high standards of investment protection. Other multilateral treaties with similar provisions on investment include the

${ }^{88}$ See Witherell H. William (1996); an Agreement on Investment, The OECD Observer, Oct-November 1996, p. 6-9. 
investment protocol of MERCOSUR, the G-3 free trade agreement, and the Energy charter treaty.

In addition to the above mentioned binding multilateral treaties, several non-binding multilateral models, guidelines and other instruments have influenced the international investment environment. These include;

-guidelines on investment and bribery by the International Chamber of Commerce, a private group.

- The United Nations model of double taxation convention and set of principles for controlling restrictive business practices

- The World Bank /international Monetary fund development committee guidelines on the treatment of foreign direct investment

\section{Bilateral agreements on the protection of investments}

\subsection{Bilateral State-to-State Agreements}

One way to reassure potential investors and to reduce the political risk perception of foreign investors is to enter into an agreement with the investor's home government in which the host stake makes commitments with respect to the investment. In the past these were generally included in what were termed treaties of friendship, commerce and navigation, or conventions of establishment. As they grew out of the nineteenth century, these constituted a medley of commercial matters. They might contain clauses as to the powers and duties of consuls, tariffs, access to ports, etc. With regard to our subject matter, political risk, they characteristically included clauses dealing with protection against expropriation, with access to courts and general national treatment provisions. By the time the United States of America had gone through a modernization program in the 1950s, it has quite a network of such agreements. For instance the USA concluded such treaties in the 1960s with Iran and Ethiopia. In the past two decades, a new form of bilateral treaty has been gaining popularity. That is the bilateral treaty or BIT as described above. These agreements could be referred to as stripped-down friendship commerce and navigation treaties. They can be quite short in format, dealing only with the protection of investment.

\subsection{Bilateral investment Treaties (BITs)}

Countries have improved the legal and policy framework for FDI through a series of bilateral investment treaties (BITs). Most of these treaties have been between an industrial country and a developing country, but recently some have been between two developing 
countries. Altogether 155 countries have been involved in one or more BITs. ${ }^{89}$ These treaties aim to improve the conditions for investment by firms of each signatory country in the other. According to ICSID, the number of BITs has expanded steadily reaching nearly 1 , 130 by May 1997.90

Following unsuccessful efforts to develop international investment agreements as part of the aborted International Trade Organization after the World War II and again in the Organization for economic Cooperation and Development in the 1960s, a number of European governments undertook programs to develop bilateral investment treaties. These efforts have resulted in over 300 BITs, mainly between European Governments and developing countries ${ }^{91}$. The United States was late in undertaking a BIT program, launching its efforts in the early 1980s. Bilateral investment treaties are international legal instruments under which each party reciprocally agrees to accord investments of the other party certain rights and to refrain from imposing a number of the more common political obstacles to foreign investment.

These treaties are generally signed between a developed, capital exporting country and a developing, capital importing country. Bilateral investment treaties cover several issues of interest to the investor: treatment of the investor after an investment has been made in a host country; expropriation, compensation and transfer of funds; dispute settlement.

The sections of a typical bilateral treaty on investment entails ${ }^{92}$ :

1. Definitions

- Investments covered

- geographic areas covered

2. General Statement Regarding Promotion and Protection of Investment

3. Treatment of the Investor

- does not include right of establishment

- generally includes fair and equitable treatment, most favored-nation treatment

4. Expropriation

- in the public interest

- for a public purpose

\footnotetext{
${ }^{89}$ See International Centre for Settlement of Investment Disputes, Bilateral Treaties, Washington DC, ICSID, 1997, p. 1., cited in International Finance Corporation (1997); Foreign Direct Investment, Lessons of Experience, Nr 5, Washington DC, p. 21-22.

90 See International Finance Corporation (1997); Ibid., p. 22.

91 UN Centre on Transnational Corporations, Transnational Corporations in World Development, Third Survey (1983), Fourth Survey (1988).

${ }^{92}$ Guertin, Donald L; Ibid., p. 122.
} 
5. Compensation

- should be prompt, adequate and effective

- some statement on how compensation should be determined

6. Transfer of Funds

- providing an effective transfer of compensation

7. Exceptions

- deals with exceptions in cases of customs unions or instances in which other international agreements cover an issue (e.g. tax treaties)

8. Dispute Settlement between Investor and Host Country

9. Dispute Settlement between Host and Home Countries

10.Government Assumption of Investors Claim if a Government makes a payment to investors.

For the foreign investor facing political risk, BITs could help to reduce political risk by achieving stability, predictability and transparency in host governmental policies affecting foreign investment. Specifically, a BIT does this by obliging each party to:

- extend national and most favored nation (MFN) treatment (with limited exceptions) to investors of the other party

- avoid (or seek to avoid) the imposition of performance requirements

- recognize that expropriation of an investor of the other party must be conducted in accordance with international law, including the payment of prompt, adequate and effective compensation

- allow investors of the other party freely to remit earnings and capital; and

- accept impartial means of settling disputes with investors of the other party, including recourse at the investor's option to the World Bank's International Center for the Settlement of Investment Disputes (ICSID) ${ }^{93}$

Another type of agreement which can be called bilateral is the agreement between the host government and the investor's home government that relates to an arrangement under which the home government insures the investment.

\footnotetext{
93 Full texts of bilateral treaties are available in ICSID publications "Investment treaties". A good overview on the profile of bilateral treaties on investment is provided in a paper presented at the 1982 Montreal Conference of the International Law Association (ILA), Permanent Sovereignty, Foreign Investment and State practice, Report for the ILA International Committee on legal aspects of a new international economic order, Peters Paul, Schrijver Nico, and deWaart paul J.I.M (1982).
} 

Corporation)

Many industrialized countries have tried in the past to deal with the political risk through the set-up of governmental guaranty companies. This is particularly the case of the United States investment guaranty program, now managed by the semi-governmental Overseas Private Investment Corporation (OPIC) ${ }^{94}$. Typically OPIC insures the American investor against expropriation loss, inconvertibility of currency or war, riot and insurrection (or against all three). It charges an insurance premium for this coverage which is specified in an elaborate agreement that has been developed over the years by OPIC and its predecessors.

As part this program, OPIC seeks assurance from the host country as to its rights over against that country in the event that the investor is able to make his case against OPIC either through negotiation or through the arbitration provided by statute and spelled out in guaranty contract. This is termed a right of subrogation. OPIC made claims before the IranUnited States claims tribunal in cases where it had paid off insured investors. ${ }^{95}$

One should note, however, that the program of OPIC is limited in substantial ways by the authorizing legislation. Thus it is the U.S. Congress and not the host country that determines the availability of insurance coverage. In addition, it is not without a price, since the insurance premium is not insignificant and will have to be recovered by the investor if the enterprise is to produce a full net profit as expected. Moreover, the coverage is not likely to reimburse the investor to the full extent of the losses of expected gains as distinguished from the original investment.

Most other developed nations utilized the mechanisms like OPIC that is, they sponsor government agencies that can insure against political risk including expropriations restrictions on the transfer of remittances and the inconvertibility of assets, war and civil strikes. This is done in Japan for example by the Ministry of International Trade and Industry (MITI); in Germany by Treuarbeit; in the United Kingdom by the Export Credits Guarantee Department (ECGD); and in Canada by the Export Development Corporation.

\footnotetext{
94 The OPIC fund was designed to be the financial engine to drive US corporate investment in Africa, and to ensure the participation of the US private sector in Africa. See Vesely Milan (1998); Has Africa missed the boat again, African Business, sept 1998, p. 31-32.

95 See Wallace Day Cynthia and Contributors (ed) (1990); Foreign Direct Investment in the 1990s, a new climate in the Third World,, Kluwer, academic Pubishers, The Netherlands.
} 


\section{Operating strategies for management of political risk}

\section{Getting FDI projects ownership structures right; Joint venture arrangement}

One way in which the political risk of FDIs could be substantially reduced resides in a conclusion of a joint venture arrangement. Ninety percent of IFC's investment projects are joint ventures between foreign and local partners. In this case, the MNC has to decide whether to choose a minority-, 50\%-or majority-owned unit. Joint ventures are defined as a separate cooperative organizational entity representing the partial holdings of two or more parent firms in which the headquarters of at least one is located outside the country of operation of the joint venture and in which both partners share risks and profits. This entity is subject to the joint control of its parent firms, each of which is economically and legally independent of other. The joint venture has been one of the contractual forms most frequently used in strategic alliances. ${ }^{96}$

In the FDI literature, the most commonly cited motives for the choice of the joint venture arrangement are: to gain rapid market entry, to increase economies of scale, to gain local know-how and local image, to obtain vital raw materials, to spread the risks and the host government's insistence. The host government's insistence has been especially important in connection with FDIs made in LDCs, whereas in FDIs made in OECD countries, know-how or resources of the partner or spreading of the risks have been of greater importance.

The research on joint ventures is twofold; The study of domestic joint ventures -all partners with the same nationality - and international joint-venture set up by partners of different nationalities. The latter has been most widely analyzed. The economic literature on international joint ventures analyze these as a mean to put the international strategy of the firm into practice. One reason which contributes to the setting up of international joint ventures are political factors. The existence of political factors make it advisable to cooperate with the local firms is a frequent reason for the creation of international joint ventures. ${ }^{97}$ Such is the case when a foreign firm wants to enter countries with hostile governments and/or restrictive legislation.

In selecting the appropriate entry mode in a given country, firms have to answer two questions; what level of control over the operation do they desire and what level of resource

\footnotetext{
${ }^{96}$ See Mariti, P/Smiley R.H (1983); Cooperative Agreements and the Organization of Industry, Journal of industrial Economics, 31, p. 437-451.

97 See Friedmann, W. G /Kalmanoff G (1961); Joint International Business Ventures, New York, Columbia University Press ; Tomlison, J. W.L (1970); The Joint Venture Process in international Business, India and Pakistan, MIT Press, Cambridge, MA ; Killing J, P (1983); Strategies for Joint Venture Success, New York, Praeger.
} 
commitment are they willing to make. These two questions can only be evaluated in the context of the risk that management thinks it may encounter in the country being considered for entry. In high political risk countries, firms may not be willing to commit resources. In countries that they perceive as low political risk, they may desire control over the operation, assuming that they can be as successful as they are with the domestic operation. Thus it is the risk perception that shapes the evaluation to the above two questions, which in turn leads to decisions regarding the choice of an entry mode strategy.

Many empirical studies include a risk variable of some form or another and find a significant relationship between the risk variable and entry mode strategy.(Brouthers, Brouthers et al (1993)). These empirical studies have defined risks as either dissemination risks or countryspecific risks. Country specific risks are defined as the external uncertainties (environmental unpredictability) in a given country (Gatignon, and Anderson (1988)). Country risk has been operationalized as risk of expropriation/repatriating income, general stability of political, social and economic conditions (Agarwal and Ramaswami (1992) and Chan and Hwang (1992)).

An IFC study of 70 joint ventures in six developing countries (Argentina, Brazil, India, Mexico, Philippines and Turkey) found that joint ventures are fragile affairs difficult to negotiate and maintain. The choice of a complementary partner was seen as the key to success. Technology transfer was found to be one of the more difficult issues. The study also found difficulties in negotiating management structures for joint ventures and latter problems in assuring clear management control, particularly as the interest evolved disputes were common over product line, sourcing of raw materials, and the use and cost of technology. ${ }^{98}$ Half of the joint ventures surveyed in the study are related to government restrictions.

Foreign investors considering joint ventures in LDCs finds that bringing a multilateral financing organization like the IFC into partnership can reduce political risk. This is particularly true of joint ventures with government or public enterprises, where the IFC's multilateral status puts it in a strong position to negotiate with governments and act as honest broker between the government and foreign investor's interest. ${ }^{99}$

Indeed, the recognition in economic literature of a close relationship between the entry mode strategy and the political risk leads in turn to a linkage between political risk and entry mode selection in the sense that political risk can be offset through the selection of an appropriate

\footnotetext{
98 Miller R. R (1996); International Joint Ventures in developing countries, IFC discussion paper 29, Washington DC .

${ }^{99}$ Foreign Direct Investment, Nr 5, Lessons of experience; Ibid., p. 73-74.
} 
entry mode. The advantage of joint venture as a selection mode in the management of political risks resides in the weak commitment of resources and capital and in the contractual flexibility of joint ventures. However, these advantages of joint ventures should be considered in conjunction with the problems generated by the joint ventures agreements themselves. These problems entail the problems of different nationalities and objectives between both parent firms which could be incompatible.

\section{Getting the financial structure of the FDI project right}

One financial operating strategy available to cope with political risk (through transfer of risks on a third party) is to finance the FDI project to the extent possible with funds from the host and other governments, from international development agencies, from overseas banks, and from customers - with payment to be provided out of production - rather than supplying parent company-raised or parent-guaranteed capital. ${ }^{100}$ In order to ensure the implementation of this financial operating strategy, MNCs must prenegotiate these conditions with host governments, that is before investment is made MNCs must reach an agreement with the host countries on these issues.

\section{Empirical studies on political risk and FDI}

\section{A. Empirical research on political risk, level of corporate risk and risk premium}

\section{Empirical research on political risk and level of corporate risk}

In international finance literature, the major factor that is associated with the reduction in systematic risk for the multinationals is that the multinational's operations are in multiple countries which increases the diversity of its cash flows. ${ }^{101}$ As a multinational is more diversified relative to a similar domestic firm, the returns of the firm will be less correlated with the market and its systematic risk may decrease.

To examine how this international diversification may change positively the systematic risk and how this change may be offset by the increased exposure to political risks we will consider the CAPM relationship $\mathrm{Rjz}-\mathrm{Rfz}=\mathrm{bj}(\mathrm{Rmt}-\mathrm{Rft})+\mathrm{t}(1)$ where $\mathrm{Rij}$ is the random return on the jth security at time $\mathrm{t}$. Rft is the risk free rate at time $\mathrm{t}$. bj is the measure of systematic risk of firm $\mathrm{j}$. Rmt is the market return at time $\mathrm{t}$; and $\mathrm{t}$ is the mean zero error term. bj can be rewritten as $b j=(\mathrm{jm} \mathrm{j} / \mathrm{m})(2)$ where $\mathrm{jm}$ is the correlation coefficient between

100 See Shapiro Alan C (1992); Ibid., p. 706.

101 See for instance Shapiro, Alan C (1978); Financial structure and the cost of capital in the multinational corporation, Journal of financial and quantitative analysis 13, p. 211-266. 
security $\mathrm{j}$ and the market. $\mathrm{j}$ is the standard deviation of firm $\mathrm{j}$ and $\mathrm{m}$ is the standard deviation of the market. Previous international finance literature posited that diversification may work to decrease the firm's systematic risk. That is, corporate internationalization should reduce $\mathrm{jm}$, as the investments in the foreign market will be less correlated with returns in domestic markets. However, internationalization may also increase exposure to political factors and other pervasive economic factors and therefore increase $\mathrm{j}$.

Adverse effects on corporate risks exist and are well- recognized. These risks includes foreign exchange risks and political risks. Reeb, Kwok and Baek(1998) argue therefore that the additional risk that the international firm may face could actually increase the firm's level of systematic risk if there is an increase in $\mathrm{j}$ greater than the decrease in jm. This suggests that the political risk is a plausible explanation why internationalization may increase the systematic risk of the multinational. Thus, the internationalization could lead to an increase in the systematic risk of the firm if $\mathrm{j}$ increases more than the decrease in jm. As Burgman (1996) points out, although international diversification can lower the volatility of earnings,

multinationals are exposed to exchange rate risk and political risk which may offset the diversification benefit by increasing the volatility of cash flows.

\section{Empirical research on political risk and risk premium}

The basic hypothesis adopted in country-risk analysis is one of a standard increasing riskreturn relationships where FDI inflows are negatively related to host-country risk, but positively related to a compensating risk premium in the form of enhanced expected return on investment (Clegg (1992), p. 64) However, because the value of the risk premium is commonly proxied by market-related locational variables, the exercise reduces research to no more than confirmation of the role of host market size and growth, and invariably political variables are subordinated to economics ones which may not truly reflect their relative importance. An improved measure of risk premium has proven elusive in this area of inquiry. Chase, Kuhle and Walther (1988) find no association between political risk and estimated risk premiums across developed and less developed countries. However the logic of diversification theory suggests that this approach is misleading because in order to predict FDI flows, a country's contribution to the risk and return of the firm's total portfolio must be known. (see for e.g. Aggarwal, R. (1980)).

\section{B. Empirical research on the linkage between political risk and FDI}

With the surge in FDI in the past decade, FDI has moved to the centre of attention in policy discussions and in the literature on international trade and finance. One of the main controversial issues discussed in the FDI literature is the question of determinants of FDI. Several studies have been carried out on determinants of DFI. There are essentially two 
ways of discovering the determinants and motives for FDI. Statistics can be used to analyze FDI patterns or company executives can be asked to describe the reasons for FDI decisions made. Thus the empirical studies trying to determine the role of political risk in investment decisions are of two types: those based on executive answers to survey questions and those based on events and FDI data.

Most empirical studies on the importance of political risk for FDI are related to FDI in developing countries (LDCs). There is also economic literature on the relationship between political risk and Direct Foreign Investment in particular of the USA in the European community. Recent examples are empirical studies of Scaperlanda (1983) or Lunn 1980).

Some studies that used statistics put more emphasis on economic variables as explanatory factors of FDI, whereas others concentrates on the political factors. Some studies put more emphasis on economic variables as explanatory factors of FDI, whereas others stress on the political factors. Thus statistical empirical dealing with the determinants of FDI concentrate on two factors: the political and the economic factors ${ }^{102}$

In considering the empirical literature investigating the influence of political risk on FDI and based on statistics, it is therefore useful to distinguish two approaches. The first approach, which can be called a genuine political-oriented approach stress on the importance of political factors as determinant of FDI and ignore the economic ones, while in the second approach, which can also be termed as an economic-oriented one, political factors are considered only as one side factor of the FDI among others. Furthermore, the economicoriented approaches are also characterized by their tendency to treat political factors in the general framework of the testing and refining of theories of MNCs.

Both economic-oriented and political-oriented empirical studies on the determinants of FDI are based on the same assumptions, namely that FDI is supply-determined, that is, determined by the decisions of multinational enterprises. Thus there is not real market envisaged for FDI. The demand in the host countries is implicitly assumed to be infinitely elastic.

Empirical studies based on surveys consistently found that executives considered host country instability to be a major deterrent in FDI project location decisions (Frank I (1980), Green, R (1972), Root, F. R. (1968), Basi, R, S (1963), Aharoni Yair (1966)) that is

\footnotetext{
102 A general Survey explaining FDI is provided by Agarwal Jamuna P (1980); Determinants of FDI, A Survey, Welwirtschaftliches Archiv, Vol. 116, p. 739-773; See also Jong de Nick and Vos Rob (1994); Theoretical and empirical Approaches to direct foreign investment; A Survey of literature, Working papersSubseries on Money, Finance and Development Nr 57, Institut of social studies, August 1994. Hague, Netherlands.
} 
executives report political risk to be the most important variable influencing their foreign investment decisions aside from market potential. A relatively recent survey research conducted by Buckley Newbould and Thurwell (1988) also points to the importance placed by foreign investors on political stability and low country risk. Empirical studies on the relevance of political risk based on statistics and FDI data, have yielded in contrast to those based on executives surveys mixed if not contradictory results. Some have found significant effects of political risk on FDI flows while other have not.

Earlier studies of relevance of political risk based on statistics failed to establish a relationship between political risk and the flows of FDI. These earlier studies includes studies by Bennett and Green (1972), Green and Cunningham (1975), Kobrin (1976) and Thunell (1977).

Bennett and Green(1972) examined the relationship between US direct marketing investment flows for 46 countries and the Feierabend index of political stability (a weighted index of politically relevant, aggressive behaviors occurring within a nation over a particular time period).

Green and Cunningham (1975) examined the relationship between US- direct manufacturing investment flows for 25 countries using 1965 data and several variables measuring political risk. Kobrin (1976) examined the relationship between the number of new manufacturing subsidiaries established in each country, the book value of manufacturing direct foreign investment, and several variables measuring political structure and unrest, economic-size and growth, and socio-economic development. Kobrin found a systematic relationship between FDI and market-potential related variables, but all political variables were found not to be related to the flow of FDI.

Finally Thunell (1977)tried to relate changes in the flow of FDI to regime changes and other events affecting political stability. Thunell, through a number of statistical tests, examines the hypothesis that investments in a country decrease when it's unstable and increase when it's stable. He finds that (1) political events are not directly associated with short-term fluctuations, but only with trend changes in foreign investment flows (2) the relationship is asymmetric, that, is, the investing companies do not react in the same way when a country becomes more stable as when it becomes unstable.

In one of the comprehensive and recent studies Nigh (1985) analyzed foreign direct investments in manufacturing in 24 countries, including 11 developing countries during 1954-1975 by multinational corporations based in United States. He found that for the developing countries in particular FDI flows are related to internal conflicts such as roots 
and civil war. Whether investors from other industrial countries are as averse to political instability is unclear.

Another study of political risk in developing countries (Brewer, T. L. (1983) found a very weak correlation between the governmental instability and their restrictions on international funds associated with FDI projects and less so than among developed countries.

The relationship of expropriation to government instability is also not consistent (Kobrin, S. J. (1984)).

Other empirical studies such as those undertaken by Yu (1987) and Brewer (1985) have analyzed the relationship between governmental regimes instability and compared developing countries and industrial countries in terms of political stability. These studies have found weak and statistically insignificant relationships among developing countries. They have also found as much or more policy instability in industrial countries as in developing countries.

Many empirical studies on the economic theory of multinationals or economic theory of international production also try to account for political risk in the form of country-specific factors and to relate political factors with FDI. An overview on some studies dealing with economic theory of MNCs and international production could therefore shed light on the relationship between political risk and FDI.

One example of a theory of MNCs dealing with political risks is provided by the "eclectic" approach of international production as propounded by Dunning ((1973), (1993)). On the basis of surveys among entrepreneurs engaged in international production, Dunning distinguishes three sets of influence on FDI, (1) market factors such as size and growth of the market measured by the GNP of the recipient country; (2) cost factors such as the availability of labor, law labor costs and inflation; (3) the investment of climate as measured by the degree of foreign indebtedness and the state of balance of payments. It's only here that political factors play a role since the investment climate is considered partly to depend on political stability.

Dunning (1981) in his eclectic model also accounts for political risk in the form of BERI (Business Environmental Risk Index) or tax burden as a determinant for FDI. Another theory of MNCs explicitly including political risk is provided by Agarwal, J.P. (1980).

In his classification of the determinants of FDI, Agarwal (1980) mentions two political factors namely political stability and the threat of nationalization in conjunction with other economic variables such as investment incentives or the degree of economic development etc. 
Root and Ahmed (1979) also try in their model to account for political risks. With the help of discriminant analysis Root and Ahmed (1979) test whether 16 economic, 5 social and 7 political factors (frequency of government change, number of internal armed attacks, degree of administrative efficiency, degree of nationalism, per capita foreign aid, colonial affiliation and role of government in the economy) have a significant influence on FDI.

Finally, Levis (1979) tests the two hypothese that economic considerations are the prime determinants of foreign investment flows and that political variables are of secondary importance. The political variables considered are political instability, a political competition index and the relations with COMECON countries (which may be an indirect indicates for political risk). The model is tested by a step-by-step regression for 25 developing countriesAfrica, Asia and Latin America- and for the period 1965-1967. As a result, the economic variables turn out to be more important than the political ones.

As we have noticed, some empirical studies put more emphasis on macro-economic variables as explanatory factors of FDI whereas other stress the importance of political variables. Nevertheless, in practice and theory, it appears difficult to make a clear-cut distinction between political and macro-economic variables.

Given this interdependence of economic and political variables, Schneider and Frey (1985) complain rightly that existing studies on determinants of FDI put either too much emphasis on economic determinants and largely treat the political variables as epiphenomenon or the other way round, or that there is an "unstructured amalgamation of economics and politics". To overcome the deficiencies both in content and statistical procedures, Schneider and Frey (1985) propose a politico-economic model. They formulate testable hypotheses on the basis of existing studies of international production and test them by a simple method (i.e. multiple regression). The model proposed by Schneider and Frey incorporates a large number of possible determinants and look successively at the results of the estimation of determinants of FDI to developing countries compared with the results of estimates with three alternative models (the political, the economic and the amalgamated model). They conclude that FDI in developing countries is simultaneously determined by economic and political factors. 


\section{Summary}

To sum up, one can say that empirical studies on the relevance of political risk for FDI are very inconclusive on the relationship between political risk and FDI. Moreover the nature, intensity and magnitude of this relationship are not specified in most empirical studies. The relative empirical inconclusivness on the relevance of political risk for FDI is due to many factors associated with the different uses and definitions of political risk. Not only is the concept of political risk itself unsatisfactory, but the relationship between political instability measures to the firm as a whole is poorly understood (Ponyter (1985)). The same applys to the relationship between governmental instability and any resulting instability in policy of host countries. Moreover, it is also possible that other national and international sources of risks exacerbate or reduce the total political risk at country level rendering it especially hazardous to isolate the specific influence of the political variable. Furthermore, the attribution of macro-economic variables such as monetary politics and fiscal politics to economic variables is misleading since macro-economic variables used in most empirical studies are not exclusively economic in the real sense but political-economic in nature. Fiscal policy, monetary policy are also political in the sense that they do not exclusively obey market forces but depend largely on political decisions.

Another shortcoming of most empirical studies is their lack of differentiation; this refers to the fact that most empirical studies use the same political variables for all sectors of economic activity without taking into consideration the fact that the definition of political risk is dependent on the kind of industry or service considered. The industry composition of FDI requires therefore incorporation as a variable in the above mentioned models since political risks probably differ significantly between industries in particular the risk expropriation appears lower to FDI with a high degree of service activity and to FDI that is vertically integrated with production outside the host country (Buckley (1989)). The most compelling conclusions to emerge are those drawn by Schneider and Frey (1985) namely that a political stability index helped in explaining FDI balance of payments inflows, but with a lesser effect than market and economic variables.

In any case, perceptions of political risk are likely to continue to affect investor's inclinations about undertaking FDI projects in particular countries and regions and especially in LDCs countries. Whereas the relative political stability in some countries like Poland, Czech, Hungarian etc. should encourage investors, the continuation of ethnically-based conflicts in some countries of central Africa like Congo, Rwanda, Burundi or in Yugoslavia or in some 
republics of former Soviet Union will surely deter many investors from undertaking projects in those areas for several more years.

Moreover, a rapid look at the rapidly growing Asian countries led to the intuitive conclusion that peace and political stability obviously have a favorable impact on perceptions of risks and expected returns from investments in private sector and must be one important element of Asian success.

One of the distinctive features of the rapidly growing Asian countries have been their basic political stability. By contrast, much of Africa has been torn apart by violent transfers of powers, colored by radical ideologies and tribal animosities. Latin America has also experienced struggles over socialist and communist ideologies; and Middle East remains embroiled in bloody conflicts over Israel and Islamic fundamentalism. During the postwar period, much of Asia emerged from a century of internal and external conflict into relative political stability; Japan in 1945, China after the final paroxysm of the cultural revolution in the 1970s, Indonesia once Suharto took control in the 1960s, Taiwan after the Kuomintang brutally established its control in the early 1950s. South Korea after the end of the Korean war, and Thailand also at the end of the World War. Indeed, those parts of the region that have most suffered from war, violent repression and severe political instability including Vietnam, Cambodia, Burma and the Philippines have the weakest economic records. ${ }^{103}$ Furthermore many of the uncertainties in the economic future of Asia, Africa and EastEurope lie precisely in this realm of political stability or risk. For instance Yeltsin is now aging in a country without a clear succession process and no one can predict the political future of Yeltsin and in particular the post-Yeltsin period and the consequences on the investor confidence and perceptions of risk is unknown.

Undoubtedly, political instability or stability has an influence on the perception of the risks by foreign investors. What remains to be demonstrated and assessed is the magnitude, the nature and the effects of the linkage between political risk and FDI. This demonstration is however because of the interrelation of psychological, politic, social, economic and cultural factors in the realm of political risk concept very difficult to quantify. This explain partly why most empirical studies on the subject remains essentially descriptive.

\section{Conclusions; The Need for a New Comprehensive Theoretical Framework}

The surge in FDI around 1980's has increased and complexifies the nature and quality of political risk faced by MNCs. The traditional framework of dealing with political risk including the efforts made to define, to assess and to manage political risk on corporate level

${ }^{103}$ Lincoln Edward J (1996); Some missing elements, Brookings papers on economic activity, p.351-355, herep. 354-355. 
was transformed in particular the management of political risk. One of the distinctive features of the modern management of political risk is the use of international institutional arrangements or framework to offset the political risk. This intensive use of institutional arrangements to manage political risks coincides with the development of an international investment law dealing with the stabilization, the transparency and the promotion of the investment area. This process of institutionalization of investment is favored by the generally positive attitude of LDCs towards the FDI.

Surely the development of accepted investment rules on international level can reduce the impact of political risk on FDI. But this shall not prevent the MNCs from undertaking measures against political risk at corporate level and to develop genuine business reactions against political risk.

In this sense research aiming to assess political risk and to integrate the political risk into capital budgeting and decision processes in the international finance and trade should be fostered and enhanced. These efforts must be done in accordance with other field of researches dealing with decisions, organization, politic, and culture. One prerequisite for the success of such an enterprise is an precise definition of political risk. In addition to the descriptive definition of political risk, a normative criterion for delimitation of political risk must be elaborated. This imply also at the same time a precise representation of the role of the State in the international economic order for without such a representation it's will be impossible to formulate an objective criterion for the normative definition of political risk

To sum up, a satisfactory normative definition and assessment of political risk is not possible without an analysis and understanding of the nature and role of the State in the international economic order. This shows once more that the problem of political risk and FDI lies in the realm of the interrelations between politic and economic, between negotiation and market. Undoubtedly the role of Nation-State and politics is undergoing a great transformation under the pressure of internationalization of economic. In the ongoing globalizing world a Nation-State cannot regulate more, cannot policy more and cannot manage more.

If the future role of the nation-State includes apart from supporting market forces, efficiently implementing the international rules, political risk should be defined as the sum of all measures which tend to breach international rules as contained in international provisions and to negate the market forces.

Indeed, insofar as one can derive from the recent development of the functions of State some lessons, one can say that it gives credit to the idea that the future role of the State will consist of; 
1. Sustaining and supporting the market forces (market-capability of the State)

2. Participating and cooperating with international organization of any kind and to implement international rules (international commitment-capability of the State)

3. Maintaining and generating civil peace and security (security-capability)

4. Revealing reliable information to civil society and international institutions(transparencycapability)

From these enumerations, one can derive that all measures which directly or indirectly are not satisfying these conditions should be counted as political risk.

To conclude, if the political risk theoretically means anything, it means thinking about the future role of Nation-States, of culture, history and geography and market forces in the shaping of the international economic order. In considering the political risks in their strategies, MNCs as the symbolic motors of the globalization should be aware of this theoretical implication. For the economic research this means that efforts should be made, not only to improve the risk/returns tradeoff of the MNCs (through predictability, quantification or integration in decision making process, risk transfer-methods and risk avoidance methods) but also to integrate the "Miwelt" and the "Umwelt", that is, to contribute to the economic and social development of the involved population in the host government and to improve the quality of their environment. In this sense, improving the social conditions of the population of host countries as well as the quality of their environment constitute one of the comprehensive and best management tools of political risk. The strategy just described calls for pertinent strategy aimed at strengthening the reputation of integrity of the subsidiary in the market place and in the public eyes. Siegwart, Caytas and Mahari (1989, p. 82) referred to them as "good will strategies" that encompass following measures;

- Support social, cultural or charitable projects

- Maintain a harmonic relationship with the media

- Maintain a conflict-free, trusting relationship with supervisory and licensing authorities

- Maintain the most comprehensive political and social contacts possible

- Contribute to legitimate goals of relevant interest groups

- Avoid any proximity to conflicts of interest or corruption

- Demonstrate a healthy loyalty to the country and to the local community

- Avoid compromising business relationships

- Observe high standards in the selection and behavior of employees

- Avoid open display of prosperity

- Exhibit generosity in salaries and working conditions. 
In addition, political risk gave and give contempory economists a great deal of trouble, for it presented both real and conceptual problems. The major conceptual difficulty lay with finding a definition of political risk that would adequate to the many new roles the NationState now played. 


\section{$\underline{\text { References }}$}

Agarwal Jamuna P (1980); Determinants of Foreign Direct Investment, A Survey, Welwirtschaftliches Archiv, Vol. 116, p. 739-773

Agarwal, Sanjeev and Ramaswami ,Sridhar N (1992); Choice of foreign Market Entry Mode, Impact of Ownership, Location and Internationalization Factors, Journal of International Business Studies 23 (1), p. 1-28

Aggarwal R. (1980); Investment Performance of US-based multinational Companies, Comment and a Perspective on international Diversification of real Assets, Journal of international Business Studies, 11 (1), p. 98-104

Agmon Tamir (1985); Political Economy and Risk in World financial Markets USA/Canada

Aharoni Yair (1966); The foreign Investment Decision Process (Cambridge Mass, Harvard Graduate School of Business

Alesina A, Oezler S, Roubini N and Siragel P (1992); Political Instability and Economic Growth NBER Working Paper nr 4173 Cambridge

Banks A (1979); Cross-national time Series data Archive, Mimeo, Center for social Analysis State University of New York, New York.

Barro R and Wolf H (1989); Data Appendix for Economic Growth in a Cross Section of Countries, Mimeo, Havard University, Cambridge

Barron Jonathan, Miranti Paul J (1997); History of Corporate Finance, Cambridge University Press 1997

Basi R. S. (1963); Determinants of United States Private Investment in Foreign Countries, Kent State University Press

Bergsten, C. F.,Horst T. and Moran T(1978); American Multinationals and American Interests, Washington D.C. , The Brookings Institution, p. 130-140

Bond Eric W and Samuelson Larry (1986); Tax Holidays as Signals, American Economics Review 76, p. 820-826

Brander, James A and Spencer, J. Barbara (1987); Foreign Direct vInvestment with Unemployment and Endogeneous Taxes and Tariffs, Journal of International Economics 22, p. 257-279

Brewer L. Thomas (1993); Foreign Direct Investment in emerging market Countries , in Global Race for Foreign Direct Investment ed by Lars Oxelheim Heidelberg 1993, P. 177-203

Brewer T. L (1985); Political Risk in International Business, new Directions for Research, Management and Public Policy, Praeger New York 
Brewer T. L. (1983); The Instability of Governments and the Instability of Controls on Funds Transfers by Multinational Corporations, Journal of International Business Studies, 14, 3, p. 147-157

Brewer T.L (1991); Integrating political Variables into Foreign Investment Theory, An Analytical Framework, Paper presented atbthe 1991 AIB Meeting in Miami.

Brouthers, Keith D /Brouthers Lance Eliot/Steve Werner and Nicoleta-Lasen, Dana (1993); An integrating Model of international Entry-mode Selection, The case of Computer Software Industry, Paper presented at the Academy of International Business annual Meeting, Hawaii, October 21-24

Brunetti Aymo (1997); Politics and Economic Growth, a Cross-country Perspective, Development Centre of OECD, OECD

Buckley Adrian (1996); Multinational Finance third ed, Great Britain

Buckley P. J. (1989); The Implications of the economic Theory of the Multinational Enterprise for Control at the international Level in Buckley P.J. (1989); The multinatinational Enterprise, Theory and applications, London Macmillan p. 113-122

Buckley P. J. and Clegg J (ed) (1991); Multinational Enterprises in less developed Countries, London Macmillan

Buckley, P. J, Newbould G. D. and Thurwell J. C. (1988); Foreign Direct Investment by smaller UK Firms, London Macmillan

Burgmann Todd (1996); An empirical Examination of Multinational Structure, Journal of International Business Studies, 27, p. 553-570

Caves Richard (1998); Research on international Business Stuidies, Problems and Prospects, Journal of International Business Studies, Symposium Multinational enterprises and Economic Analysis, Vol. 29, Nr 29, First Quater, p. 5-19

Chase C. D./Kuhle J. L./Walther C. H. (1988): The relevance of political Risk in Direct Foreign Investment, Management International (MIR), Vol. 28, 1988/3, p. 31-38.

Clark Ephraim (1997); Valuing Political Risk, Journal of International Money and Finance, Vol 16, Nr 3, p. 477-490

Clarke N. Ellis (1990); Foreign Direct Investment and International Capital Flows to Third World Nations, U.S. Policy consideratios, p. 1-27 in ; Foreign Direct Investment in the 1990s, a new Climate in the Third World, ed. by Wallace Day Cynthia and Contributors, Kluwer, Academic Publidshers, The Netherlands

Clegg Jeremy (1992); Explaining Foreign Direct Investment Flows in multinational Enterprises in the World Economy, Essay in Honour of John Dunning ed. by Peter. J. Buckley and Mark Casson

DeAnne Julius(1991); The neglected Twin of Trade published by Group of Thirty, Washington D.C. 
Doyle Chris and Van Wijnbergen (1984); Taxation of foreign Multinationals, a sequential Bargaining Approach to Tax Holidays, University of Stockholm, Institute for International economic Studies, Seminar Paper 284

Dunning J. H (1993); Multinational Enterprises and the Global Economy, Workingham, Addison-Wesley.

Dunning John H (1973); The Determinants of International Production, Oxford Economic Papers, Vol. 25, November 1973, p. 289-336

Dunning, John H (1981); Explaining the International Direct Investment Position of Countries, Towards a dynamic or developmental Approach, welwirtschaftliches Archiv, Vol. 117 , p. 30-64

Eng V. Maximon, Lees A. Francis, Mauer, Laurance.J (1998); Global finance, 2nd. ed.

Feis Herbert (1965); The World's Banker (1870-1914), A Account of european Foreign Investment and the Connection of World Finance with Diplomacy before World War I (IX Preface), Yale University Press.

Frank I (1980); Foreign Enterprise in Developing Countries, Baltimore M.D. JohnHopkingd University p. 111-112

Friedmann W. G /Kalmanoff G (1961); Joint International Business Ventures, New York Columbia University Press

Froot A. Kenneth (1993); Foreign Direct Investment ed by Froot A. Kenneth, The University of Chicago Press

Fry H. Earl (1983); The Politics of international Investment, New York, Mc Graw-Hill Book Company

Gatignon, Hubert and Anderson Erin(1988); The Multinational Corporation's Degree of Control over foreign subsidiaries, A empirical Test of a Transaction Cost Explanation, Journal of Law Economics and Organization, Fall 1988, p. 305-366

Graham M. Edward and Krugman Paul R. (1993); The Surge in Foreign Direct Investment in the 1980s, in Foreign Direct Investment ed by Froot A. Kenneth, University of cHicago Press, p. 13-36

Green R. (1971); Political Instability as a Determinant of US Foreign Investment, Austin, University of Texas.

Green R. (1972); Political Instability as a Determinant of US Foreign Investment, austin University of Texas

Grilli, V., Masciandro D. and Tabellini G. (1991); Political and Monetary Institutions and public financial Policies in the industrial Economies, Economic Policy, $\mathrm{Nr}$ 13, October 
Guertin, Donald L (1990); A Program Leading to an International Agreement on Foreign Direct Investment, p. 119-147 in; Foreign Direct Investment in the 1990s, a New Climate in the Third World ed by Wallace Day Cynthia and Contributors, Kluwer Academic Publishers, The Netherlands

Haendel Dan (1979); Foreign Investments and the Management of Political Risk, Westview Special Studies in International Economics and Business.

Haner F.T. with Ewing Jon S. (1985); Country Risk Assessmernt, Theory and World wide Practice, Praeger Special Studies, USA

Howell LLewelly D and Chaddick Brad (1994); Models of Political Risk for Foreign Investment and Trade, an Assessment of three Approaches, Columbia Journal of World Business, Vol XXIX, Nr 3, p. 70-91

Hymer Hebert Stephen (1976); The International Operations of national Firms, a Study of Direct Investments, The MIT Press, Cambridge, London England

ICSID Cases; 1972-1987

ICSID; Document ICSID/12

International Centre for Settlement of Investment Disputes (1997); Bilateral Investment Treaties, Washnington D.C. ICSID

International Finance Corporation (1997); Foreign Direct Investment, Lessons of Experience, Nr 5, Washington D.C.

Jong de Niek and Vos Rob(1994); Theoretical and Empirical Approaches to Direct Foreign Investment, a Survey of Literature, Working Paper-Sub-Series on Money, Finance and Development- Nr. 57, Institut of Social Studies, The Hague, The Netherlands.

Kelly Margaret (1974); Evaluating the Risk of Expropriation, Risk Management, January.

Killing J. P (1983); Strategies for Joint Venture Success, New York Praeger

Kim, W. Chan and H. Wang Peter (1992); Global Strategy and Multinationals Entry Mode Choice, Journal of International Business Studies 23 (1), p. 29-54

Kobrin S J (1979); Political Risk, a Review and Reconsideration, Journal of Internatonal Business Studies 10, p. 67-80

Kobrin S. J. (1976); The environmental Determinants of Foreign Direct Manufacturing Investment, an ex post empirical Analysis, Journal of International Business Studies, 7 (2), p. 29-42

Kobrin S. J. (1984); The Expropriation as an Attempt to control foreign Firms in LDCs, International Studies quareterly 28, 3, p. 348-357

Krayenbuehl Thomas E (1985); Country Risk Assessment and Monitoring, Cambridge 1985. 
Krueger, A. O (1974); The political Economy of the Rent Seeking Society, American Economic review (June), p. 291-303

Landau D (1986); Government and Economic Growth in the LDCs, an empirical Study for 1960-1980, Economic Development and Cultural Change Vol. 35, Nr 1 October

Larimo Jorma (1993); Foreign Direct Investment Behaviour and Performance, an Analysis of Finnish Manufacturing Investments in OECD Countries, Acta Wasaensia, Nr 32, Business Administration Nr 13, Universitas Wasaensis, VAASA 1993

Lecraw D.J. (1991); Factors influencing Foreign Direct Investment by transnational Corporations in host developing Countries, a preliminary Report in Buckley P. J. and Clegg J. (ed), p. 163-180

Lejong Nick and Vos Rob(August 1994); Theoretical and economic Approaches to Direct Foreign Investment, a Survey of Literature, Institut of social Studies, Working

Lesni 1 (1989); Bargaining with Commitment, Choice of Techniques, and Direct Foreign Investment, Journal of International Economics, 26, p. 77-97

Levis Mario (1979); Does political Instability in developing Countries affect Foreign Investment Flow ? An empirical Examination , Management International Review Vol 19 , p. $59-68$

Lincoln Edward J (1996); Some missing Elements, Brooking Papers on Economc Activity (2), p. 351-355

Lunn John (1980); Determinants of Us Direct Investment in the EEC, Furthet Evidence, European economic Review, Vol 13, p. 93-101

Mahajan Arvind (1990); Pricing Expriopriation Risk, Financial Management, Winter 1990, p. $77-85$

Mariti, P/Smiley R. H. (1983); Cooperative Agreements and the Organization of Industry, Journal of industrial Economics, 31, 1983, p. 437-451

Miller R. R. (1996); International Joint Ventures in developing Countries, IFC Discussion Paper 29, Washington D.C.

Moran. H. Theodore (1986); The future of Foreign Direct Investment in the Third World in . Investing in Development; New Roles for Private Capital, ed. by Moran H. Moran and Contributors, New Brunswick, N.J; Transaction Books

News from ICSID, Winter, June 30, 1987

Nigh D. (1985); The effects of political Events in United States direct Foreign Investment, Journal of International Busines Studies, 16, 1, p. 1-17

OECD Study (1989); International Investment and Multinational, Incentives and Disincentives, Effects on International Direct Investment, OCDE Paris

Oxelheim Lars (1993); The global Race for Foreign Direct Investment, Prospects for the Future ed by Oxelheim Lars, Heidelberg 
Paper Subseries on Money Finance and Development, Nr 57, The Hague, The Netherlands

Peters Paul, Schrijver Nico, Dewaart J, Paul J.I.M (1982); International Committee on Legal Aspects of a New International Economic Order, Montreal Conference on Permanent Sovereignty, Foreign Investment and State Practice.

Poynter T. A. (1985); Multinational Enterprises and Government Intervention, New York St Martin's Press

Raff Horst (1991); A Model of expropriation with asymetric Information, Working Paper Nr 9105, Université Laval, Department of Economics

Reeb M. David, Chuck C.Y Kwok and Young H Baek (1998); Systematic Risk of the multinational Corporation, Journal of International Business Studies 29, Second Quarter , p. 263-279

Robock S. H. (1971); Political Risk, Identification and Assessment, Columbia Journal of World Management Science 4, p. 141-183

Robock, S.H and Simmonds, K (1973); International Business and Multinatonal Enterprise, R. Irwin, Homewood

Roddock D (1986); Assessing Corporate Politica Risk, Rowman and Littlefield Publishers, Totowa, N.Y

Rodrik Dani (1997); The paradoxes of the successful State, European Economic Review 41 (April 1997), p. 411-442.

Root F. R (1968); Attitudes of American Executives towards foreign Government and Investment Opportunities, Economic and Business Bulletin, 2. p. 1-9

Root Franklin R and Ahmed A. Ahmed (1979); Empirical Determinants of manufacturing direct Foreign Investment in developing Countries, Economic Development and cultural Change Vol 27 (July 1979) p. 751-767

Roubini N (1991); Economic and political Determinants of Budget Deficit in developing Countries, Journal of International Money and Finance, Vol 10, Supplement March

Rummel J. Rudolf and Heenan David A (1978); How Multinationals analyze Plitical Risk, Havard Business Review, January-February 1978, p. 67-76

Scaperland Anthony and Balough Robert S (1983); Determinants of US Direct Investment in the EEC, European Economic Review, Vol 21., p 381-390

Schneider F. and Frey Bruno S (1985); Economic and Political Determinants of Foreign Direct Investment, World Development, Vol 13, Nr 2, p. 161-175

Schweitzer Nicholas (1976); Bayesian Analysis for Intelligence, Some Focus on the Middle East, Paper delivered at the International Studies Association Meeting, Toronto, Canada, February 1976 
Sethi, P.S. and Luther K. N. (1986); Political Risk Analysis and Direct Foreign Investment, Some Problems of Definition and Measurement, California Management Review 28, p. 57-68

Shapiro Alan (1978); Fiancial Structure and the Cost of Capital in the Multinational Corporation, Journal of financial and quantitative Analysis 13, p. 211-66

Shapiro C. Alan (1992); Multinational financial Management 4ed USA

Siegwart, Hans, Caytas, Ivo G. and Mahari Julian I (1989); Global Political Risk, Dynamic managerial Strategies, Basel/Frankfurt am Main, Helbing u. Lichtenhahn 1989

Skinner J (1987); Taxation and Output Growth, Evidence from African Countries, NBER working Paper Nr 2335, Cambridge

Stapenhurst Frederick (1992); Political Risk Analysis aroung the North Atlantic, New York, St Martin's Press 1992, XIV

Stobaugh R. Jr (1969); How to analyse Foreign Investment Climates, Havard Business Review, Sept/Oct, p. 100-108.

Stonehill A and Nathanson L (1968); Capital Budgeting for the Multinational Corporation, Financial Management, 7, p. 7-16

Strauch Ralph (1980); Risk Assessment as a subjective Process, The Rand Paper Series ed. by Rand Corporation, March

Taylor C and Hudson M (1983); Handbook of plitical and social Indicators, Yale University Press, New Haven, Third ed.

Thomas Jonathan and Worrall Tim (1990); Foreign Direct Investment and the Risk of Expropriation, Kiel nWorking Paper Nr 411, February

Thunell H. Lars (1977); Political Risks in International Business, Investment Behavior of Multinational Corporations, Praeger special Studies in International Business, trade and Finance, Praeger Publishers, USA.

Tomlison J. W. L (1970); The Joint Venture Process in international Business, India and Pakistan.

UN Centre on Transnational Corporations; Transnational Corporations in World Development, Third Survey (1983), Fourth Survey (1988)

United Nations Conference on Trade and Development (UNCTAD) Secretariat (1995); Recent Developments in international Investment and Transnational Corporations, Trends in Foreign Direct Investment, Geneva 21 February 1995

Vernon R (1968); Conflict and Revolution between Foreign Direct Investors and Less Developed countries, Public Policy 18, p. 333-351

Vernon R (1971); Sovereignty at Bay, New York, Basic-Books 
Vesely Milan (1998); Has Africa missed the boast again, African Business, Sept.1998, p. 31-32.

Veugelers Reinhilde (1993); Reputation as a Mechanism alleviating opportuinistic Host Government Behavior aganist MNEs, The Journal of Industrial Economics 41, p. 117

Voss J (1987); Status, Mandate, Concept, Features, Implications, Journal of World Trade Law, August

Weiss, E (1990); The long Path to the IBM-Mexico Agreement, an Analysis of the Microcomputer Investment Negotiations 1983-1986, Journal of International Business Studies 21, p. 565-96

Winham R. Gilbert (1996); International Trade Policy in a globalizing Economy, International Journal, Vol LI, Nr 4 Autumn 1996, pp.641

Witherell H. William (1996); An Agreement on Investment, The OECD Observer, OctNov 1996, p. 6-9

Yongsae Choi and Haidi Salehi Esfahani (1998); Direct Foreign Investment and Expropriation, a mitigating Role for Match-specific Capital, Quarterly Review of Economics and Finance Vol. 38, Nr 1 Spring 1998, p. 47-59

Yu C. (1987); A reconsideration of measures of Instability, Journal of comparative economics 11 , p. 116-119 